\title{
Sex Discrimination in Employer-Sponsored Insurance Plans: A Legal and Demographic Analysis*
}

Lea Brilmayer, $\uparrow$ Richard W. Hekeler, $\uparrow \dagger$ Douglas Laycock $\dagger \uparrow \dagger$ and Teresa A. Sullivan $\dagger$ †ो†

The Supreme Court's decision in City of Los Angeles v. Manhart $^{1}$ has stimulated a new round of debate over the legality of sexually segregated actuarial tables under Title VII of the Civil Rights Act of 1964. ${ }^{2}$ Manhart held illegal an annuity plan in which both sexes would receive equal periodic benefits at retirement although women paid larger periodic contributions while working. The Court rejected the argument that underlies all uses of such tables-that the statistical association between sex and mortality justified the disparity. The decision has produced a vigorous counterattack by the insurance industry and some employers, ${ }^{3}$ as well

* We have had helpful exchanges with many of our colleagues, including Walter Blum, Frank Easterbrook, Spencer Kimball, Paul Meier, Bernard Meltzer, and Geoffrey Stone in the Law School, Philip Hauser, Dennis Hogan, Evelyn Kitagawa, William Parish, and William Wilson in the Population Research Center, Robert Gardner, Andrew Mason and Robert Retherford of the East-West Population Institute, Deborah Freedman and Ronald Freedman of The University of Michigan, William Van Alstyne of Duke University, Mary Gray of American University, and Cookie Stephan of New Mexico State University. John Mangum provided valuable research assistance. In accord with scientific custom, the authors' names are in alphabetical order to indicate equal responsibility.

$\dagger$ Assistant Professor of Law, The University of Chicago.

t† Graduate Fellow in the Population Research Center, The University of Chicago.

t†† Professor of Law, The University of Chicago.

tt† Assistant Professor of Sociology and Faculty Research Associate in the Population Research Center, The University of Chicago. Sullivan's work was supported by Biomedical Research Support Grant No. PHS 5 S07 RR-07029-14.

2435 U.S. 702 (1978).

2 Civil Rights Act of 1964, §§ 701-718, 42 U.S.C. §§ 2000e-2000e-17 (1976 \& Supp. II 1978).

${ }^{3}$ See, e.g., Comments of Teachers Insurance and Annuity Association of America and the College Retirement Equities Fund on Proposed Amendments to the Equal Pay Act Interpretive Bulletin (Comments submitted Oct. 23, 1978 to Director, Div. of Equal Pay and Employment Standards, Wage and Hour Div., U.S. Dep't of Labor) [hereinafter cited as TIAA-CREF Comments] (on file with The University of Chicago Law Review); Joint Brief of Appellees Colby College, Teachers Insurance and Annuity Association and College Retirement Equities Fund, EEOC v. Colby College, 589 F.2d 1139 (1st Cir. 1978) [hereinafter cited as Colby College Brief] (on file with The University of Chicago Law Review). But see 
as some scholars. The literature in support of the Court anticipated only some of the new arguments. ${ }^{\mathrm{s}}$

The controversy arises because, in the United States at present, men have somewhat higher age-specific death rates and a lower median age at death than women. ${ }^{6}$ Segregated actuarial tables reflect this difference in one of two ways. The first method is to construct separate tables for each sex based upon actual mortality data. The second, and rougher, technique is known as setting back the male table; a table is constructed for men and then applied to women after subtracting a fixed number of years from each woman's age. ${ }^{7}$ For example, a life insurance premium calculated for sixty-year-old men might also be charged sixty-threeyear-old women. Life insurance is cheaper for women than for men if segregated tables are used. Conversely, such tables make annuity benefits cheaper for men than for women. Integrated tables reflect the mortality experience of all employees, pooling the data from both sexes. When integrated tables are used, men and women bear equal costs for life insurance and annuities.

TIAA-CREF to Adopt a Unisex Mortality Table for Future Annuity Purchases (Press Release, Dec. 18, 1979) (on file with The University of Chicago Law Review).

- Kimball, Reverse Sex Discrimination: Manhart, 1979 Am. B. Foundation Research J. 83; Meltzer, Letter to Director (Comments submitted Oct. 20, 1978, to Director, Office of Federal Contract Compliance Programs) (on file with The University of Chicago Law Review). See also Rutherglen, Sexual Equality in Fringe Benefit Plans, 65 VA. L. REv. 199 (1979) (criticizing Manhart as wrong in principle but concluding that it states the only workable rule).

- This literature makes the fundamental point that Title VII requires equality for individuals and that equality for individuals requires integrated tables. But there has been little effort to reconcile this conclusion with the situations in which Title VII has been construed to require some form of equality for groups. None of this literature squarely addresses the claim that using sex to predict longevity is quite different from using sex to predict employment qualifications and that an exception should be read into the statute to accommodate this difference. Finally, this literature has tended to concede that sex would be a good predictor of mortality if Title VII did not prevent its use. The most helpful of this literature is Key, Sex-Based Pension Plans in Perspective: City of Los Angeles, Department of Water and Power v. Manhart, 2 Harv. Women's Civ. Rights L. Rev. 1 (1979); Van Alstyne, Equality for Individuals or Equality for Groups: Implications of the Supreme Court Decision in the Manhart Case, 62 AAUP BuLL. 150 (1978). See also Underwood, Law and the Crystal Ball: Predicting Behavior with Statistical Inference and Individualized Judgment, 88 YALE L.J. 1408 (1979).

- U.S. Bureau of the Census, Statistical Abstract of the United States, 1979, at 70-73 (100th ed. 1980) [hereinafter cited as Statistical Abstract]; National Center por Health Statistics, Dep't of Health, Education \& Welfare, Vital Statistics of the United States, 1976 (1979). For definitions of "age-specific death rate" and "median age at death," see notes 180,183 infra.

' See Kimball, supra note 4, at 109. Most insurers use setbacks. Id. Setbacks are a crude approximation of actual experience. 
There are three possible resolutions to the controversy. Title VII may require integrated tables; ${ }^{8}$ it may require segregated tables; ${ }^{9}$ or it may permit employers to choose between the two. ${ }^{10}$ This article adopts the first position. The statutory section demonstrates that basing benefits on segregated actuarial tables is disparate treatment of individuals under Title VII, that such disparate treatment is the primary target of the statute, and that there is no basis for a special exception to permit segregated actuarial tables. The article then reviews the scientific literature on sex mortality differences. It demonstrates that, contrary to the conventional wisdom, the association between sex and mortality is neither stable nor uniform. The substantial variations over time and space suggest that sex mortality differences probably have environmental and behavioral causes, and that any sex-linked genetic component interacts with and is heavily influenced by environmental and behavioral factors.

Our own view of Title VII does not depend on the demographic evidence. A thorough scientific analysis is nonetheless essential, for erroneous assumptions about the association between sex and mortality have played an important role in the Manhart literature. Some of Manhart's critics rely on such assumptions, and the demographic evidence is offered primarily to refute them.

- This has been the uniform holding of the courts. See City of Los Angeles v. Manhart, 435 U.S. 702 (1978); EEOC v. Colby College, 589 F.2d 1139 (1st Cir. 1978), rev'g 439 F. Supp. 631 (D. Me. 1977); Peters v. Wayne State Univ., 476 F. Supp. 1343 (E.D. Mich. 1979); Spirt v. Teachers Ins. \& Annuity Ass'n, 475 F. Supp. 1298 (S.D.N.Y. 1979); Henderson v. Oregon, 405 F. Supp. 1271 (D. Ore. 1975). This is also the position of the Equal Employment Opportunity Commission. 29 C.F.R. $\& 1604.9(\mathrm{e})$-(f) (1978). Although the guidelines may be ambiguously phrased, no one doubts the Commission's intent. See Kimball, supra note 4, at 93 n.28. See also Reilly v. Robertson, 266 Ind. 29,360 N.E.2d 171 (holding segregated annuity tables unconstitutional), cert. denied, 434 U.S. 825 (1977).

- Several critics of integrated tables imply this position. See Gerber, The Economic and Actuarial Aspects of Selection and Classification, 10 Fonum 1205, 1227-28 (1975); Hedges, Gender Discrimination in Pension Plans: Comment, 44 J. Risk \& INs. 141, 143-44 (1977); Kimball, supra note 4, at 102-03, 105, 137; Myers, Further Comment, 44 J. Risk \& INs. 144, 145 (1977); TIAA-CREF Comments, supra note 3, at 12, 15, 17, 34, 36-37. See also King, Men, Women, and Life Annuities, 43 J. Risk \& INs. 553, 563-65 (1976) (arguing that employer can contribute more for women than men but cannot apply integrated tables to employees' contributions).

${ }^{10}$ The Wage and Hour Administrator took this position for several years, see 29 C.F.R. $\S 800.116$ (d) (1978), but had announced his intention to withdraw this rule before his authority was transferred to the EEOC. See note 58 infra. Some critics of integrated tables take this position, at least in the alternative. See Kimball, supra note 4, at 128-29; Meltzer, supra note 4, at 2; TIAA-CREF Comments, supra note 3, at 18-30. 


\section{The Legal Analysis}

\section{A. Disparate Treatment, Disparate Impact, and Segregated Tables}

1. Individuals v. Groups. Proponents of both integrated and segregated tables claim to offer sexual equality; the disagreement is over whether the unit of analysis should be the individual or the group. Consider an annuity plan with two thousand participants, half male and half female, each of whom made equal contributions to the plan and retired at the same age. Proponents of segregated tables attempt ${ }^{11}$ to assure that the sum of all benefits paid to the thousand men will equal the sum paid to the thousand womenthat sexual groups will be treated equally. But the result is sexual inequality for individuals: every man will receive a larger periodic benefit than any woman, and a man and a woman of equal longevity will receive unequal total benefits. Integrated tables take the opposite approach, achieving equality at the individual level while risking an unequal distribution of total benefits to the two groups.

The question, therefore, is whether in this context Title VII requires equality for individuals or equality for groups. One reason for the vigorous and so far unproductive disagreement about the answer may be that most of the antagonists come from fundamentally different intellectual traditions with respect to the individuals-versus-groups issue. The insurance tradition analyzes risks, premiums, and benefit schedules in terms of groups; most actuaries cannot think of individuals except as members of groups. ${ }^{12}$ As we shall show, ${ }^{13}$ however, the main civil rights tradition analyzes rights in terms of individuals. Its most fundamental principle has been that no individual shall be considered simply as part of a racial, sexual, religious, or ethnic group, or treated differently because of his membership in such a group.

The issue has been further complicated by the introduction into Title VII law of analyses based, in whole or in part, on equality for groups. The first such innovation was the disparate-impact theory-that facially neutral employment practices with unequal effects on racial or sexual groups violate Title VII if not justified

11 They can never succeed. See text at notes 277-279 infra.

12 See, e.g., TIAA-CREF Comments, supra note 3, at 27 ("Insurance by its nature requires reference to groups").

${ }^{13}$ See text at notes $37-83$ infra. 
by business necessity. ${ }^{14}$ Another was the authorization of voluntary group-based remedies to integrate traditionally segregated occupations. ${ }^{15}$ These developments have somewhat blurred the traditional emphasis on individuals in civil rights law. They lend colorable support to efforts to read theories of group equality derived from insurance policy into Title VII, but as we shall demonstrate, ${ }^{16}$ the insurance industry's theory is an unwarranted extension of disparate-impact theory.

Despite the introduction of these group theories into Title VII law, the prohibition of disparate treatment of individuals remains dominant. Manhart relied on this disparate-treatment theory, ${ }^{17}$ in which the essence of the wrong is to ignore individual characteristics and treat individuals on the basis of group affiliation, as when an employer refuses to hire an applicant because he is black. ${ }^{18}$ Perhaps ironically, ${ }^{10}$ disparate treatment is the oldest, narrowest, and least controversial theory of discrimination.

The leading disparate-impact case is Griggs $v$. Duke Power Co. ${ }^{20}$ in which an employer required a high school diploma and a passing test score as conditions of employment for certain positions. Although the requirement did not explicitly differentiate between blacks and whites, it had unequal impact on racial groups because a smaller percentage of blacks had diplomas and passed the test. Consequently, the requirement was held unlawful unless the employer could show "business necessity" for it-that the employment requirement was actually related to job performance. ${ }^{21}$

As Griggs illustrates, criteria that cannot be used by an employer under Title VII may be statistically associated with other

14 See Griggs v. Duke Power Co., 401 U.S. 424 (1971).

15 See United Steelworkers v. Weber, 443 U.S. 193 (1979).

16 See text at notes $47-65,71-83$ infra.

17435 U.S. at 708-09.

18 See, e.g., Furnco Constr. Corp. v. Waters, 438 U.S. 567 (1978); McDonnell Douglas Corp. v. Green, 411 U.S. 792 (1973).

10 Many critics of Manhart take a narrow view of the statute and are hostile to theories of group equality in other contexts. Thus, Chief Justice Burger and Justice Rehnquist, the only dissenters from the individual approach in Manhart, were also the only dissenters from the group approach in Weber. On the other hand, Justices Stewart, White, and Marshall joined the majority opinions in both cases. Similarly, compare Meltzer, supra note 4 with Meltzer, The Weber Case: The Judicial Abrogation of the Antidiscrimination Standard in Employment, 47 U. CHI. L. REv. 423 (1980).

${ }^{20} 401$ U.S. 424 (1971). Other important disparate-impact cases are New York City Transit Auth. v. Beazer, 440 U.S. 568 (1979) and Dothard v. Rawlinson, 433 U.S. 321 (1977).

21401 U.S. at 431. 
criteria in which employers are legitimately interested. When such an association exists, employers intent on pursuing the legitimate criterion inevitably run afoul of either disparate-impact or disparate-treatment theory. If they distinguish on the basis of the forbidden criterion, as a way of predicting the legitimate one, they are guilty of disparate treatment. If they use the permissible criterion directly, they will cause disparate impact, since by hypothesis that criterion is associated with the forbidden one. In the latter case, employers must show a business necessity for using the permissible criterion. ${ }^{22}$

Which theory applies in the event of litigation thus depends on how an employer formulates his requirement. The classic illustration is Bowe v. Colgate-Palmolive Co., ${ }^{23}$ in which the employer refused to hire women for certain manufacturing jobs because employees in those jobs had to lift heavy weights. The exclusion of women was disparate treatment, and illegal. ${ }^{24}$ The fact that many women were unable to lift the weights was irrelevant to the case of a woman who could; sex could not be used to predict her weightlifting ability. The company was permitted, however, to require applicants for these jobs to pass a weight-lifting test. ${ }^{25}$ This policy would have disparate impact on women, and the company would have to justify it by showing business necessity-in this case, that lifting the weights was necessary to operation of the plant. Note that in the disparate-impact case, individuals of equal weight-lifting ability would be treated alike, regardless of their sex; in the disparate-treatment case, individuals of equal weight-lifting ability but different sex would be treated differently. In short, the test of disparate treatment is whether any difference in treatment remains after controlling for all variables other than sex.

The association between sex and mortality is no different from any other association between forbidden and permissible criteria. American women as a group currently live longer than American men as a group, just as they are able to lift less weight as a group. But some women will die earlier than some men, just as some will be able to lift more weight. An employer who pays annuities on the basis of integrated tables in effect distinguishes among his employees on the permissible basis of longevity, for those individuals who

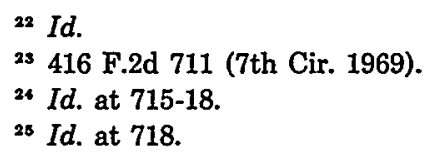


live the longest will collect the most periodic payments and thus the largest total sum. Of course, the employer's practice may have disparate impact on men, for as a group they may not live to collect as many periodic payments as women. If he tries to avoid this disparate impact by using segregated tables-making larger periodic payments to all men as a group-he distinguishes on the basis of sex. This would be disparate treatment, for individual men and women of equal longevity would be treated differently: ${ }^{26}$ both periodic benefits and total benefits will be greater for a man than for a woman of equal longevity. ${ }^{27}$

2. The Expectancy Argument. Professor Kimball attempts to avoid this analysis by arguing that one should not compare actual cash benefits received, either periodic or total. Rather, he suggests, one must compare the expected values of the annuities as of the date of retirement. ${ }^{28}$ Because women as a group live longer than men as a group, he argues that each woman has a greater life expectancy than each man. It would follow that under a properly constructed segregated annuity table that provides larger periodic benefits to men, the expected value of future payments would be the same for all individuals. Actual longevity would be irrelevant, for "[t]heir expectations were identical at the beginning." concludes that a sexually integrated actuarial table "is a pure

${ }^{28}$ It has been suggested that to predict on the basis of a person's sex is to treat him more individually than to predict simply on the basis of his being human. City of Los Angeles v. Manhart, 435 U.S. 702, 727-28 (Burger, C.J., concurring in part and dissenting in part); Kimball, supra note 4, at 119. But this misses the point of Title VII. The statute does not require that people be treated individually in some absolute or abstract sense; it requires that they be treated individually with respect to race, sex, religion, and national origin. A person is treated individually with respect to sex if no generalization based on real or supposed average characteristics of his sex is applied to him.

${ }^{27}$ One might argue that an annuity based on segregated tables is the economic equivalent of a lump sum retirement benefit of equal size for both sexes, and that it is arbitrary to call the former disparate treatment and the latter equal treatment. But the two alternatives are not economically equivalent for individuals. Just as it is necessary to compare individuals of equal weight-lifting ability in the case of sex and weight lifting, it is necessary to compare individuals of equal longevity in the case of sex and longevity. A man and a woman who retire at the same age and die at the same age will receive equal total benefits from an annuity paid under integrated tables, or from an equal lump sum distribution at retirement. Either is equal treatment.

${ }^{28}$ Kimball, supra note 4, at 101-02.

29 Id. at 102. Similar arguments are made by Colby College Brief, supra note 3, at 4-6; Hedges, supra note 9, at 141-43; Kimball, supra note 4, at 122-23, 137; King, supra note 9, at 560-62; Rutherglen, supra note 4, at 242-43, 247-48; Meltzer, supra note 4, at 5-6; TIAACREF Comments, supra note 3 , at 10-12, 23-25. 
fiction, a way of concealing the truth."30

This expectancy argument begs the question in a fundamental way. The ultimate issue is precisely whether mortality data may be classified by sex for the purpose of paying annuities-that is, whether sex may be used to predict longevity. No expectancy can be calculated until that question has been answered. The statement that some particular person is expected to live some certain number of years is dependent on a prior decision about how to classify that person. ${ }^{31}$ It is circular to use the expectancies generated by a predictor to justify using that predictor. This may be illustrated by a simple example.

Consider the life expectancy of a newborn black male in South Carolina. Prediction of his life expectancy may or may not take into account his sex, race, and residence. If he is classified as a nonwhite male South Carolinian, his life expectancy is 58.33 years. If he is classified simply as a resident of the United States, his life expectancy is 70.75 years. The other possibilities range in between; he may be a nonwhite South Carolinian, a male South Carolinian, a nonwhite male American, a male American, a nonwhite American, or a South Carolinian. He has eight different life expectancies $^{32}$-and just on the basis of the three predictors intro-

so Kimball, supra note 4 , at 138.

31 In statistics textbooks, expectancy or "arithmetic mean" is always defined by reference to some particular body of data. See, e.g., J. Freund, Modern Elementary Statistics 33 (4th ed. 1973); R. Hogg \& A. Craig, Introduction to Mathematical Statistics 34 (2d ed. 1965).

32

EXPECTATION OF LIFE AT BIRTH

(Selected Categories, 1969 - 1971)

\begin{tabular}{lcc}
\hline \hline & United States & South Carolina \\
\hline All persons & 70.75 & 67.96 \\
All males & 67.04 & 63.85 \\
All non-whites & 64.95 & 62.64 \\
Non-white males & 60.98 & 58.33
\end{tabular}

Source: Greville, Some Trends and Comparisons of United States Life-Table Data: 1900-1971, in 1 NATIONAL CENTER FOR HeALTH STATISTICS, DeP'T of Health, Education \& Welfare, U.S. Decennial Life Tables for 1969-71, No. 4 Table 4 , at $4-10$ (1975). 
duced so far. We could generate many more expectancies by considering such predictors as urban or rural residence, socioeconomic status, and family medical history.

No one of these expectancies is any more statistically valid than the others. ${ }^{33}$ Our hypothetical infant is a member of all eight groups; all eight expectancies are his expectancies. A newborn black female in South Carolina has a greater life expectancy only if one has already decided to use sex as a predictor; if sex is not used, the two infants have identical expectancies. Thus, an "equal expected value" test is futile: it can be satisfied by either integrated or segregated tables. ${ }^{34}$

The relationship between data classification and expectancy is obscured by talking in terms of the "average man" and the "average woman," for that language presupposes that data will be classified by sex. The terminology does, however, highlight what employers are doing when they classify data by sex: they are treating every woman as though she were at the mean of the distribution for women, and every man as though he were at the mean of the distribution for men. Professor Kimball's individual expected values are merely applications of group averages to individuals, ${ }^{35}$ and that is quintessential disparate treatment. His insistence that seg-

ss In a certain sense, a prediction might be said to be "truer" the more information it took into account. If this is the criterion, our hypothetical infant must be treated as a black male South Carolinian - and, the prediction must be made more detailed if possible. But no insurance company would so classify him; he would be treated as a male American, or just an American. Adding more predictors does not necessarily make the prediction more accurate; relying on an unstable or spurious association may make the prediction less accurate. See Kimball, supra note 4, at 112. This supposed criterion of "maximum predictive power" is also frequently overridden because the expectancies generated may not be administrable at an acceptable cost, id. at 107-08, 118-20, or socially acceptable, CoMmitTEE ON RISK CLASsipication, American Academy of Actuaries, Risk Classification Statement of PrinciPLEs 20-21 (Exposure Draft, Oct. 19, 1979) [hereinafter cited as Risk Classification] (on file with The University of Chicago Law Review). The important point is that no "true" expectancy can be generated by purely mathematical methods; considerations of social policy and administrative convenience are always called into play.

34 "Actuaries know that 'actuarial equivalence' is not an absolute measure but one which depends upon the mortality and interest assumptions made beforehand." Anderson, A Critique of the Manhart Brief, The Actuary, May 1978, at 6. Anderson indicates that it is error "to imply the existence of an absolute actuarial equivalence," id., and that there "is no compelling actuarial reason" to use sex as a predictor, $i d$. at 7 .

${ }^{3 s}$ The general problem is discussed in A. Ayer, Probability and Evidence 52 (1972). After a discussion about why there is no "true" individual expectancy, Ayer argues that an expectancy that seems to describe individuals can only be understood as an elliptical statement about the distribution of some property in a group. He concludes that "the judgments of probability of which the frequency theory gives an adequate account are those in which we are not concerned with individual cases." Id. 
regated tables equalize the expected value of benefits to be paid is simply a reformulation of the claim that segregated tables provide equal benefits to the two sexes considered as groups. As another critic of Manhart acknowledges, this argument against integrated tables is based on their disparate impact. ${ }^{36}$

The effect of the expectancy formulation is merely to obfuscate the real issue: may sex be used to calculate life expectancy in the first place? To answer that question, one must resolve the apparent conflict between disparate treatment and disparate impact.

\section{B. The Meaning of the Statute}

The 88th Congress, which adopted the Equal Pay Act of $1963^{37}$ as well as Title VII, addressed itself to the choice between disparate treatment and disparate impact. Those terms were not yet coined, but the concepts are evident in the legislative debates and in the texts of both statutes.

Opponents of Title VII repeatedly charged that the bill would lead to quotas and would ban all employment practices that interfered with proportionate representation of protected groupsthose that had a disparate impact. ${ }^{38}$ There was particular concern about seniority rules, because blacks would have no seniority with employers who had previously refused to hire them, ${ }^{39}$ and about ability tests, ${ }^{40}$ because a state hearing examiner had just suggested that tests with disparate impact on blacks, even if job related, violated Illinois's antidiscrimination law.". Thus, the underlying conflict between equality for groups and equality for individuals was already presented, along with some of the most important practical applications of disparate-impact theory.

The proponents of Title VII repeatedly answered that the bill provided equal opportunity for individuals and banned what we would now call disparate treatment. Senator Humphrey, the majority floor manager of the bill, offered the following definition

${ }^{36}$ Rutherglen, supra note 4, at 247-48. See Gerber, supra note 9, at 1228; Hedges, supra note 9, at 144; Kimball, supra note 4, at 103-05.

${ }^{37} 29$ U.S.C. $\$ 206(d)$ (1976).

${ }^{38}$ See United Steelworkers v. Weber, 443 U.S. 193, 201-08 (1979) (collecting legislative history); id. at 231-52 (Rehnquist, J., dissenting) (same).

${ }^{39}$ See International Bhd. of Teamsters v. United States, 431 U.S. 324, 350-51 (1977).

${ }^{40}$ See Griggs v. Duke Power Co., 401 U.S. 424, 434 (1971).

41 Myart v. Motorola Inc., No. 63C-127 (Ill. Fair Empl. Prac. Comm'n, Feb. 26, 1964), reprinted in 110 CoNG. Rec. 5662 (1964), enforcement denied sub nom. Motorola Inc. v. Illinois Fair Employment Practices Comm'n, 34 Ill. 2d 266, 215 N.E.2d 286 (1966). 
of discrimination: "[T]he meaning of racial or religious discrimination is perfectly clear .... [I]t means a distinction in treatment given to different individuals because of their different race, religion, or national origin."42 Similar statements appear throughout the legislative history; ${ }^{43}$ no proponent of the statute ever suggested that groups as such were to be treated equally. ${ }^{44}$ The same unambiguous emphasis on equal treatment of individuals appears in the statutory text. It is unlawful for an employer to

4110 Cong. Rec. 5423 (1964) (remarks of Sen. Humphrey).

is See, e.g., id. at 1540 (remarks of Rep. Lindsay); id. at 6000, 6553, 13088 (remarks of Sen. Humphrey); id. at 6564 (remarks of Sen. Kuchel); id. at 7207 (interpretive memorandum prepared by Department of Justice and introduced into record by Sen. Clark); id. at 7213 (interpretive memorandum prepared by Sens. Clark and Case, the bipartisan captains responsible for Title VII); id. at 7253 (remarks of Sen. Case); id. at 9881 (remarks of Sen. Allott); id. at 14465 (brief description of Title VII from Bi-Partisan Civil Rights Newsletter No. 28, inserted into record by Sen. Hart). The frequent references to quotas and racial balance in these statements simply reflect that that was the context in which the choice between individual and group equality was most squarely posed. The same principle that precludes systematic efforts to maintain racial balance in the allocation of jobs precludes attempts to maintain sexual balance in the allocation of annuity benefits. Congress was aware that its debate over racial balance involved an issue of general principle that turned on the meaning of "discriminate"; opponents of the bill repeatedly complained that the word had not been defined in the bill and would be construed in a way that required racial balance. See H.R. REP. No. 914, 88th Cong., 1st Sess. 67-68 (1963) (Minority Report), reprinted in [1964] U.S. Code Cong. \& AD. News 2391, 2436; 110 Cong. Rec. 8428 (1964) (remarks of Sen. Robertson); id. at 14311 (remarks of Sen. Thurmond); id. at 15892 (remarks of Rep. Meader).

"The only significant discordant note in the legislative history is Senator Humphrey's famous statement that the Bennett amendment would permit employers to set different retirement ages for men and women. 110 CoNG. Rec. 13663-64 (1964). This statement is irrelevant to the choice between individual and group equality; it would permit open discrimination against both individuals and groups, without a hint of an actuarial or any other rationale. It is so inconsistent with any conceivable meaning of the statutory language, and so inconsistent with any other views advanced by either side in the legislative history, that it has been generally disregarded by the courts. In Manhart, the Supreme Court concluded that this "isolated comment on the Senate floor cannot change the effect of the plain language of the statute itself." 435 U.S. at 714. And sex differences in retirement ages, the very subject of Senator Humphrey's comment, have been struck down by the lower courts. Rosen v. Public Serv. Elec. \& Gas Co., 477 F.2d 90 (3d Cir. 1973); Bartness v. Drewrys U.S.A., Inc., 444 F.2d 1186 (7th Cir.), cert. denied, 404 U.S. 939 (1971). The Supreme Court relied on Senator Humphrey's statement in General Elec. Co. v. Gilbert, 429 U.S. 125, 144 (1976), but Congress quickly expressed its disapproval of that case, without mentioning the Senator's statement, H.R. REP. No. 948, 95th Cong., 2d Sess. 2 (1978), reprinted in [1978] U.S. CoDE Cong. \& AD. NEws 4749, 4750. The academic proponents of segregated tables have not relied on Senator Humphrey's statement. For further analysis of the statement, see Bernstein \& Williams, Title VII and the Problem of Sex Classification in Pension Programs, 74 Colum. L. Rev. 1203, 1218 n.50 (1974); Gold, Equality of Opportunity in Retirement Funds, 9 Loy. L.A. L. REv. 596, 599-602 (1976); Lines, Sex-Based Fringe Benefits-Annuities and Life Insurance, 16 J. FAM. L. 489, 504-06 (1978). 
(1) ... refuse to hire or to discharge any individual, or otherwise to discriminate against any individual . . . because of such individual's . . . sex . . . or (2) . . . classify his employees or applicants . . . in any way which would deprive any individual of employment opportunities or otherwise adversely affect his status . . . because of such individual's . . . sex .....45

The statutory text and legislative history taken as a whole thus leave no room for doubt. There is consensus that the original congressional understanding of discrimination, and the primary target of the statute, was disparate treatment of individuals. ${ }^{48}$

The conflict between disparate treatment and disparate impact was faced most directly in a number of provisions limiting disparate-impact liability, the most important of which for our purposes are the exceptions to the Equal Pay Act. These exceptions are incorporated into Title VII by the Bennett amendment, ${ }^{47}$ which provides that "differentiation" by sex in compensation does not violate Title VII if the differentiation is authorized by the Equal Pay Act.

The Equal Pay Act forbids discrimination in pay on the basis - of sex, except where the pay differential is based on seniority, merit, productivity, or "any other factor other than sex." 4 At first reading, this language presents a conundrum. The exception seems to protect a nonexistent category: discrimination on the basis of sex that is not on the basis of sex. But in the context of the objections made by congressional opponents of antidiscrimination legislation, the meaning is clear. It is that disparate impact in pay does not violate the Equal Pay Act, and hence does not violate the ban on sex discrimination in Title VII: one sex as a group may earn more than the other if the difference is based on seniority, merit, productivity, or any factor other than sex itself.

45 U.S.C. $\$ 2000 \mathrm{e}-2(a)$ (1976) (emphasis added).

${ }^{4}$ See International Bhd. of Teamsters v. United States, 431 U.S. 324, 335 n.15 (1977); B. Schlei \& P. Grossman, Employment Discrimination Law 1 (1976); Kimball, supra note 4 , at 91 n.22.

17110 CoNG. Rec. 13647 (1964) (codified at 42 U.S.C. $§ 2000$ e-2(h) (1976) (second sentence)) (floor amendment proposed by Sen. Bennett and approved by voice vote).

18 No employer . . . shall discriminate . . . on the basis of sex by paying wages . . . at a rate less than the rate at which he pays ... the opposite sex... except where such payment is made pursuant to (i) a seniority system; (ii) a merit system; (iii) a system which measures earnings by quantity or quality of production; or (iv) a differential based on any other factor other than sex.

29 U.S.C. § $206(d)(1)$ (1976) (emphasis added). 
The brief debate on the Equal Pay Act bill focused on these exceptions in response to opposition led by Representative Findley. He argued that the bill would deprive women of employment opportunities because it made no allowance for the additional costs that he believed were associated with hiring women-costs that opponents of the bill attributed to higher turnover, restrictive state legislation, the need for special facilities, and female responsibilities as mothers and homemakers. ${ }^{49}$

Proponents of the bill responded that most differences in costs could be calculated on an individual basis, ${ }^{50}$ and rejected the Findley amendment, which was apparently intended to permit costs to be calculated on the basis of sexual categories..$^{51}$ Representative Griffin offered the clearest explanation of how costs could be considered under the bill. ${ }^{52} \mathrm{He}$ analyzed assumed associations between sex and time worked and between sex and absenteeism in precisely the way we have analyzed the association between sex and mortality. ${ }^{5 s}$ The employer could not use sex to predict absenteeism, but he could penalize absenteeism even if that caused disparate impact on women. Representative Goodell, a key sponsor of equal-pay legislation, also argued that costs could be considered if calculated with respect to particular employees and not on the basis of sexual categories. $^{54}$

4 H.R. REP. No. 309, 88th Cong., 1st Sess. 10 (1963) (additional views of Rep. Findley), reprinted in [1963] U.S. CodE CoNG. \& AD. NEws 687, 691-92; 109 CoNG. REc. 9205 (1963) (remarks of Rep. Findley); id. at 9213 (remarks of Rep. Fisher); Kimball, supra note 4, at 133-34 (reviving the objection); Meltzer, supra note 4, at 1, 4-5 (same). See also Bernstein \& Williams, Sex Discrimination in Pensions: Manhart's Holding v. Manhart's Dictum, 78 Colum. L. REv. 1241, 1242-47 (1978) (proposing a dubious prophylactic rule to remedy the problem); Bernstein \& Williams, supra note 44, at 1212-13 (same).

so 109 Cong. Rec. 9217 (1963) (remarks of Rep. Goodell). Thus, proponents of the bill claimed that the Findley amendment was redundant: considering costs on an individual basis would give the employer the same savings as considering them on a group basis. Even so, proponents said only that "most" costs could be computed individually; they did not say "all" costs.

s1 The proposed amendment would have permitted "a differential which does not exceed ascertainable and specific added cost resulting from employment of the opposite sex." Id.

109 Cong. Rec. 9205-06 (remarks of Rep. Griffin).

s3 See text at notes 25-27 supra.

s4 109 Cong. REc. 9206, 9217 (1963) (remarks of Rep. Goodell). It might be argued that, if an insurer charges an employer one rate for each man and a higher rate for each woman, the employer may pass these rates on to his employees as an individually calculated cost difference. But these cost differences do not reflect individual differences; they reflect the fact that the employer has chosen to do business, and to require his employees to do business, with an insurer who calculates costs on the basis of group averages. If that were permissible, actuarial arguments would be irrelevant; the insurer could cover men for free and 
We do not mean to suggest that Congress in 1963 had thought through all the implications of the distinction between disparate treatment of individuals and disparate impact on groups, or that it fully understood and specifically contemplated the application of that distinction to insurance. Indeed, Congress had not yet formulated its ideas with sufficient precision to express them in clear and concise statutory language. The drafters ineptly used "on the basis of sex" and "based on ... sex" in the same sentence to mean quite different things; the sentence would be nonsensical if both phrases had the same meaning. The Findley amendment was also ambiguous, as were some comparably concise statements in the legislative history. ${ }^{65}$ But there is no ambiguity in the statements by sponsors of the bill who took time to explain what they meant and to illustrate their points with examples. The legislative history taken as a whole leaves little doubt that the key distinction was between consideration of differences among individual employees and consideration of sexual group averages-the same distinction that dominated the debates on Title VII a year later.

The first interpretive rules issued by the Wage and Hour Ad-

charge double or triple for women, and the employer could pass these charges on to women as individual costs. No one claims that that is the law. The passing-on argument was not addressed in the legislative history. Representative Griffin assumed in an illustration that an employer could pay women less if they worked shorter hours because of state laws requiring rest periods for women. 109 CoNG. Rec. 9205-06 (1963). But this does not cast light on the passing-on argument because in 1963 the employer could have imposed discriminatory restperiod rules directly. Representative Griffin was discussing the Equal Pay Act bill, which affected only compensation; Title VII's ban on discrimination in terms and conditions of employment was enacted a year later.

A variation of the passing-on argument is that periodic annuity benefits are not the proper measure of compensation, because they are not received pay period by pay period in direct exchange for work, but that instead, either the employer's contribution or the present actuarial value of the future periodic benefits is the measure. Kimball, supra note 4, at 9799,137 . The flaw in the reasoning is the claim that the employer's contributions are always equal to the employee's compensation, see id. at 101. Suppose the employer contributed $\$ 1,000$ to an annuity plan for his male employees and $\$ 1,000$ to purchase albatrosses for his female employees. The contributions would be equal, but the compensation would not be, even if he paid a fair market price for the albatrosses. Compensation is what the employees receive for the employer's contribution. See Van Alstyne, supra note 5, at 155. In the case of an annuity plan, they receive contractual entitlements to future payments, subject to certain contingencies. Employees receive these entitlements pay period by pay period, if that matters. The value of the entitlements is the present expected value of the future payments, and that, as we have noted, depends on whether sex is used to calculate the expectancy. See text at notes 28-36 supra.

Bs S. Rep. No. 176, 88th Cong., 1st Sess. 4 (1963); 109 Cong. Rec. 9200 (1963) (remarks of Rep. Dwyer). Neither of these statements is inconsistent with the view that cost cannot be calculated on the basis of sexual groups. 
ministrator were consistent with this legislative history. He construed the Equal Pay Act exceptions as permitting disparate impact but not disparate treatment, and concluded that sex could play no part $^{\mathrm{se}}$ in the calculation of wage differentials based on other factors. A subsequent interpretive rule specifically addressed the claim that the average cost of hiring women exceeded the average cost of hiring men, and concluded that wage differentials based on such average differences violated the Act, for the differentials would necessarily be applied to individual workers on the basis of sex. ${ }^{57}$ This interpretive rule was relied on in an early district court decision rejecting, as a defense to a charge of disparate treatment, the argument that insurance costs for unemployment compensation, workmen's compensation, and accident and health coverage were higher for women. ${ }^{58}$

Exceptions similar to those in the Equal Pay Act were written into Title VII itself, and provide a valuable analogy. Section $703(h)^{59}$ protects discrimination on the basis of seniority, merit, productivity, location, or ability tests. The exceptions contain the same arguable conundrum as the Equal Pay Act. Since discrimina-

so 29 Fed. Reg. 5555 (1964) (codified at 29 C.F.R. $\$ 800.142$ (1979)).

${ }^{87} 31$ Fed. Reg. 2657 (1966) (codified at 29 C.F.R. $\$ 800.151$ (1979)).

ss Wirtz v. Midwest Mfg. Corp., 18 Wage and Hour Cas. 556, 560 (S.D. Ill. 1968). The two interpretive rules described in text have never been repealed or modified, but the Administrator seemed to consider them inapplicable to employee-benefit plans. Instead, he issued an interpretive rule that gave employers the option of using either segregated or integrated tables. 29 C.F.R. $\S 800.116(d)$ (1978). This rule is inconsistent with the more general rules that sex cannot be the cause of pay differentials and that no allowance can be made for average cost differences between the sexes. The Administrator never explained or justified the exception, and after Manhart he announced his intention to withdraw it in favor of a rule requiring integrated tables. 43 Fed. Reg. 38,029 (1978). No action was taken on the proposal because enforcement responsibility was transferred to the EEOC. 43 Fed. Reg. 19,807 (1978).

39 Notwithstanding any other provision of this subchapter, it shall not be an unlawful employment practice for an employer to apply different standards of compensation, or different terms, conditions, or privileges of employment pursuant to a bona fide seniority or merit system, or a system which measures earnings by quantity or quality of production or to employees who work in different locations, provided that such differences are not the result of an intention to discriminate because of race, color, religion, sex, or national origin, nor shall it be an unlawful employment practice for an employer to give and to act upon the results of any professionally developed ability test provided that such test, its administration or action upon the results is not designed, intended or used to discriminate because of race, color, religion, sex or national origin. It shall not be an unlawful employment practice under this subchapter for any employer to differentiate upon the basis of sex in determining the amount of the wages or compensation paid or to be paid to employees of such employer if such differentiation is authorized by the provisions of section 206 (d) of title 29 .

42 U.S.C. \& $2000 \mathrm{e}-2(\mathrm{~h})$ (1976). 
tion on the basis of seniority, merit, productivity, location, or ability test is not on the basis of race, sex, religion, or national origin, the exceptions are arguably meaningless. But again, the meaning is clear in context. Section 703(h) was inserted to allay fears, mentioned earlier, ${ }^{60}$ that seniority, merit, productivity, and ability tests would be held illegal because of disparate impact on blacks. The Supreme Court has consistently construed section 703(h) in this way. In International Brotherhood of Teamsters $v$. United States, ${ }^{61}$ the Court noted that seniority would be illegal under disparate-impact theory were it not for the seniority clause. ${ }^{62}$ In Griggs $v$. Duke Power Co., ${ }^{63}$ the Court read the testing clause to express congressional rejection of the view that any test with disparate impact was illegal. ${ }^{64}$

In sum, the 88th Congress feared that its antidiscrimination legislation would be construed as forbidding disparate impact in situations where that was not intended, and it responded with badly drafted exceptions that can only be construed to mean that disparate impact is not forbidden in the various circumstances indicated. The Bennett amendment thus disposes of the controversy. Equal periodic annuity benefits are not illegal discrimination against men, for the amendment permits disparate impact on either sex in compensation. ${ }^{85}$ If it happens that men as a group collect less than women as a group, the difference is due to some "factor other than sex," namely, actual longevity. Just as men as a group may get higher wages if they have greater average seniority, women as a group may collect higher total pension benefits if more of them live longer.

The Bennett amendment also refutes the more restrained argument that Title VII leaves employers free to use either integrated or segregated tables. This argument is based on alleged legislative silence: since segregated actuarial tables were not explicitly

${ }^{60}$ See text and notes at notes 38-41 supra.

61431 U.S. 324 (1977).

${ }^{62} I d$. at $349-50$.

63 401 U.S. 424 (1971).

ot Id. at 434-36. Both the seniority and testing clauses are limited by provisos, International Bhd. of Teamsters v. United States, 431 U.S. 324, 353 (1977); Griggs v. Duke Power Co., 401 U.S. 424, 436 (1971); see note 59 supra; many tests and some seniority systems are unprotected. But the provisos are irrelevant for present purposes; what matters is that the main clauses, which parallel the Equal Pay Act exceptions, have been construed as authorizing disparate impact.

BS This argument is made in Manhart, 435 U.S. at $710 \mathrm{n} .20,713 \mathrm{n} .24$, but too succinctly for some commentators, see Kimball, supra note 4, at 124 . 
addressed in the statutory text or legislative history, and since it would have been controversial to prohibit them, Congress cannot be presumed to have done so. ${ }^{68}$ But this is a curious form of legislative-silence argument. No one has suggested that Title VII is inapplicable. ${ }^{67}$ That would permit unlimited extra payments to men without regard to actuarial tables. Rather, the argument is that the statute requires some form of equality in the insurance context, but that Congress must have meant to allow the employer to choose either individual or group equality.

The statute should not be construed on the basis of such speculation. Congress made a deliberate choice between the principles of no-disparate-treatment-of-individuals and no-disparate-impacton-groups. In the context of sex and compensation, the Bennett amendment and the Equal Pay Act exceptions explicitly reflect that choice. The task of statutory construction is to apply to particular cases the principle Congress selected, not to speculate about what principle it might have chosen had it debated employer-sponsored insurance plans at greater length. Congress was not required to list all potential applications, or even all controversial applications. $^{68}$ The principle itself was controversial, as was the inclusion of sex within the principle. ${ }^{69}$ Moreover, Congress was not unaware that the principle had implications for insurance benefits. ${ }^{70}$

This view of the statute is supported by the congressional response to General Electric Co. v. Gilbert, ${ }^{71}$ in which the Supreme Court held that Title VII is not violated by the exclusion of pregnancy from an otherwise comprehensive disability insurance plan. Congress promptly required that pregnancy be covered on the same terms as any other disability, ${ }^{72}$ announcing that this had been its original intent. ${ }^{73}$ And Congress so reacted despite evidence that disability insurance cost more for women than men even with-

Bs Kimball, supra note 4, at 95 n.35.

e7 Professor Kimball acknowledges that annuities are "compensation" within the meaning of Title VII. Kimball, id. at 97-99.

ss See Daniel v. Paul, 395 U.S. 298, 307-08 (1969). See also Busic v. United States, 100 S. Ct. 1747, 1752 (1980).

sP See 110 Cong. Rec. 2577 (1964) (remarks of Rep. Celler).

70 See id. at 13490-92 (1964) (remarks of Sen. Dirksen and vote of Senate) (refusing to add age to list of forbidden criteria for fear of disrupting insurance plans); Bernstein \& Williams, supra note 44, at 1218-19; Lines, supra note 44 , at 500-01.

71429 U.S. 125 (1976).

7242 U.S.C. \& $2000 \mathrm{e}(\mathrm{k})$ (Supp. II 1978).

${ }^{73}$ H.R. REP. No. 948, 95th Cong., 2d Sess. 2 (1978), reprinted in [1978] U.S. ConE Cong. \& AD. News 4749, 4750. 
out pregnancy coverage; such coverage would require employers to spend an additional $\$ 191.5$ million per year on female employees. ${ }^{74}$ Thus the statutory provision rejects both the view that the amount spent on men as a group should equal the amount spent on women as a group, and its corollary, that cost calculations can be based on sexually segregated actuarial tables.

The Bennett amendment compels the conclusion that segregated tables violate Title VII, because it speaks directly to the meaning of sex discrimination in compensation. But the argument does not depend on the Bennett amendment; that provision simply reflects the underlying values that led to the statute's enactment and inform its construction. When the ban on disparate treatment conflicts with the partial ban on disparate impact, the former must control.

Yet Manhart's critics argue for the opposite; they would encourage or require disparate treatment as a remedy for the disparate impact caused by paying benefits subject to a life contingency. The same argument would suggest eliminating the disparate impact of a test by adding points to the scores of the disadvantaged racial group. That has not been the customary remedy; instead, courts have enjoined use of the test unless its continued use was justified by business necessity. ${ }^{75}$ Similarly, the disparate impact of benefits subject to life contingencies could be eliminated by eliminating the life contingency. ${ }^{76}$ But that is neither required nor wise; there is consensus that such contingencies are a business necessity. ${ }^{77}$ It follows that unequal total payments to sexual groups are

74 Id. at 9, reprinted in [1978] U.S. CoDE CoNG. \& AD. News at 4757. See also General Elec. Co. v. Gilbert, 429 U.S. 125, 130-31 nn.9-10 (1976).

${ }^{75}$ The two Supreme Court decisions holding tests illegal are Griggs v. Duke Power Co., 401 U.S. 424 (1971), and Albemarle Paper Co. v. Moody, 422 U.S. 405 (1975). Neither specified the remedy, but each opinion implied that unvalidated tests with disparate impact cannot be used. 422 U.S. at 436 ("outright reversal" of holding that tests were job related "implied that an injunction should immediately issue against all use of testing"); 401 U.S. at 431 ("If an employment practice which operates to exclude Negroes cannot be shown to be related to job performance, the practice is prohibited"); $i d$. at 436 . The lower courts have generally enjoined all use of such tests. E.g., Walston v. School Bd., 566 F.2d 1201, 1203-04 (4th Cir. 1977); Jones v. New York City Human Resources Admin., 528 F.2d 696 (2d Cir. 1976); Boston Chapter, NAACP, Inc. v. Beecher, 504 F.2d 1017, 1026 (1st Cir. 1974), cert. denied, 421 U.S. 910 (1975); Pennsylvania v. O'Neill, 465 F. Supp. 451 (E.D. Pa. 1979). But see Kirkland v. New York State Dep't of Correctional Servs., 482 F. Supp. 1179 (S.D.N.Y. 1980), discussed in note 80 infra. Some lower courts have ordered quota hiring as a remedy, B. Schlei \& P. Grossman, supra note 46 , at 1199-1221, and some defendants may have complied with such orders by adjusting minority test scores.

${ }^{78}$ See Kimball, supra note 4, at 132-33.

7z For explanations of the benefits of life contingencies, see id.; Meltzer, supra note 4, 
legal. In any event, disparate treatment of individuals is a violation, not a remedy.

This conclusion is not changed by the new Uniform Guidelines on Employee Selection Procedures. ${ }^{78}$ These Guidelines apparently attempt to authorize employers to add points to the scores of disadvantaged groups when tests have differential validity. ${ }^{79}$ That is the testing situation most analogous to segregated actuarial tables, but it rarely exists in the real world, and the guideline has not been tested in litigation. ${ }^{80}$ The new guideline is an erroneous interpretation of the statute, ${ }^{81}$ for the same reasons that preclude the use of segregated actuarial tables..$^{82}$ The proper remedy is to enjoin the use of differentially valid tests. Even if the guideline is valid, the Bennett amendment precludes its extension to sex in life insurance and annuities. ${ }^{83}$

at 4, 8; TIAA-CREF Comments, supra note 3, at 34. On the business-necessity defense generally, see Comment, The Business Necessity Defense to Disparate-Impact Liability Under Title VII, 46 U. CHI. L. REv. 911 (1979).

78 Uniform Guidelines on Employee Selection Procedures (1978), 29 C.F.R. $\S 1607$ (1979).

70 Id. § 1607.14.B(8)(d) (1979). A test has differential validity if it predicts for one race and not another, or if it predicts differently for different races. In the new guidelines, this phenomenon is referred to as "unfairness."

so The literature on differential validity is collected in Lerner, Washington v. Davis: Quantity, Quality and Equality in Employment Testing, 1976 Sup. CT. REv. 263, 294-95. Differential validity was found in Kirkland v. New York State Dep't of Correctional Servs., 482 F. Supp. 1179 (S.D.N.Y. 1980). The court relied on the guideline and approved a consent decree providing for adjustment of minority test scores. Intervenors who challenged the consent decree did not question the validity of the guideline.

s The EEOC guideline is entitled to deference but is not a regulation with the force of law. See General Elec. Co. v. Gilbert, 429 U.S. 125, 141-43 (1976); Espinoza v. Farah Mfg. Co., 414 U.S. 86, 94 (1973).

${ }^{82}$ Some applicants of both races will perform better on the job than predicted by their test score, and some will perform worse, just as some men and women will live longer than predicted and some will die sooner. To adjust all black scores upward may equalize group averages in this situation, but it would be unfair treatment of individuals: blacks who would not perform better than predicted would get an undeserved advantage, and whites who would perform better than predicted would not get the advantage given similarly situated blacks. Race would be used as a predictor of job performance in order to offset disparate impact. The guideline cannot be upheld on this rationale, though some applications of it might conceivably be upheld on the group-remedy rationale of United Steelworkers v. Weber, 443 U.S. 193 (1979), discussed in text at notes 92-95 infra. There is no indication that the EEOC is aware of the tension between this guideline and its guidelines on life insurance and annuities, 29 C.F.R. $\S 1604.9(\mathrm{e})$-(f) (1979), and on disparate treatment in testing, id. § 1607.11.

Bs A prima facie case of illegal disparate impact is a prerequisite to application of the differential-validity guideline. The Bennett amendment precludes such a prima facie case by providing that disparate impact by sex in compensation is not illegal. See text and notes at notes 47-66 supra. 


\section{The Case for an Exception}

The ban on disparate treatment is not quite absolute; narrow exceptions have been recognized. But segregated actuarial tables are unlikely subjects for such an exception, because the argument in their favor depends upon the principle of group equality that Congress so plainly refused to enact. The burden of overcoming congressional silence thus falls on those who would imply an exception.

1. Existing Exceptions. There is only one explicit exception to the statutory prohibition of sex-based disparate treatment. An employer may hire one sex exclusively if sex is a bona fide occupational qualification ("BFOQ"). ${ }^{84}$ This exception is "extremely narrow." "ss So far, the Supreme Court has upheld a. BFOQ defense only where an applicant's inability to perform was found to result from her "very womanhood," tors merely associated with sex. The BFOQ defense therefore does not authorize use of sex to predict other facts such as longevity. And whatever its breadth, the BFOQ exception is inherently inapplicable to segregated actuarial tables because they do not set occupational qualifications. ${ }^{87}$ Rather, they affect compensation for employees who are admittedly qualified.

The lower federal courts have almost uniformly recognized a second exception, not mentioned in the statute: grooming standards that differ by sex. ${ }^{88}$ These cases seem to rest either on the rationale that there is no difference in treatment if grooming standards of comparable strictness are applied to both sexes, ${ }^{89}$ or that

8442 U.S.C. $\S 2000 \mathrm{e}-2(\mathrm{e})$ (1976).

${ }^{85}$ Dothard v. Rawlinson, 433 U.S. 321, 334 (1977).

${ }^{86} I d$. at 336. For an explicit statement that statistical associations cannot be the basis of a BFOQ defense, see Rosenfeld v. Southern Pac. Co., 444 F.2d 1219, 1225 (9th Cir. 1971). See 29 C.F.R. § 1604.2(a)(ii) (1979).

87 The statutory language unambiguously limits the defense to occupational qualifications. Even if the language were less explicit, the defense could not be extended to discrimination in compensation, for that would implicitly amend the Equal Pay Act despite clear congressional intent, reflected in the Bennett amendment, not to do so.

sa See B. Schlei \& P. Grossman, supra note 46, at 344-60; id. at 99-100 (Supp. 1979).

s9 This was also the rationale of a recent holding that an employer may refuse to hire men with a sexual preference for men even though it hires women with a sexual preference for men. Desantis v. Pacific Tel. \& Tel. Co., 608 F.2d 327, 331 (9th Cir. 1979). But cf. Faraca v. Clements, 506 F.2d 956 (5th Cir.) (illegal to discriminate against applicants who are married to a'spouse of the opposite race), cert. denied, 422 U.S. 1006 (1975). The Desantis court relied on congressional refusals to amend Title VII explicitly to prohibit discrimination on the basis of sexual preference. 608 F.2d at 329. Professor Rutherglen has implied that the homosexuality cases, the grooming cases, and the sexual-privacy cases, see B. ScHLEI \& P. 
any discrimination involved is trivial. Efforts to extend this exception to more burdensome ${ }^{90}$ or more offensive $e^{9 x}$ disparate treatment have been unsuccessful. Segregated actuarial tables cannot be justified as a grooming standard or by a more general triviality exception, for they cause men and women of equal longevity to pay or receive substantially different amounts of money.

A third exception was recognized in United Steelworkers $v$. Weber, ${ }^{22}$ in which the Supreme Court upheld temporary disparate treatment by private employers attempting "to eliminate conspicuous racial imbalance in traditionally segregated job categories." Although the Court has not yet applied the rule to sex, ${ }^{94}$ Weber is the strongest support for segregated tables, for it is the only Supreme Court holding that exempts disparate treatment from Title VII by focusing on groups instead of individuals. The affirmative action plan in Weber gave blacks preferential treatment, not because the individual beneficiaries of the plan had been discriminated against, but because other blacks had been. The plan was intended to give blacks as a group a fairer share of available jobs. Similarly, the argument for segregated annuity tables is not that any particular man will fail to collect a proportionate share of all the dollars paid into the plan, but that men as a group will fail to do so.

Despite this similarity, the Weber exception does not justify segregated mortality tables. The Court's holding in Weber was based on its perception of a temporary need for extraordinary measures to correct undeniable past wrongs. The Court focused on groups only to allow private action that would help remedy widespread but concededly individual discrimination. ${ }^{95}$ Segregated ta-

Grossman, supra note 46 , at 290-92, may be explained by a common principle: the law will be accommodated to "the prevailing heterosexual ethic of American society." Rutherglen, supra note 4, at 206. This rationale is also inapplicable to actuarial tables.

'o Laffey v. Northwest Airlines, Inc., 366 F. Supp. 763, 773-74, 790 (D.D.C. 1973), aff'd on other grounds, 567 F.2d 429 (D.C. Cir. 1976).

21 Allen v. Lovejoy, 553 F.2d 22 (6th Cir. 1977).

02443 U.S. 193 (1979).

93 Id. at 209 (footnote omitted).

- But see Califano v. Webster, 430 U.S. 313 (1977) (applying a similar rule to sex under equal protection analysis); Schlesinger v. Ballard, 419 U.S. 498 (1975) (same); Kahn v. Shevin, 416 U.S. 351 (1974) (same).

95 The Weber remedy is novel; the Supreme Court has authorized judicially imposed remedies only for individually identifiable victims of discrimination. See International Bhd. of Teamsters v. United States, 431 U.S. 324, 356-77 (1977). Nevertheless, the Court plainly viewed the quota in Weber as a remedy of sorts. The Court found it necessary to take judicial notice that blacks had been excluded from craft unions, 443 U.S. at 198 n.1, and it 
bles, however, are not offered as a temporary group remedy for past individual discrimination.

Finally, some of Manhart's critics have suggested that the Bennett amendment authorizes disparate treatment in order to avoid disparate impact. ${ }^{98}$ We have already demonstrated that this analysis is unsound.97 If the Bennett amendment were so construed, an employer could justify paying men more than women simply by demonstrating an association between sex and some other variable he could legitimately seek to measure; the discrimination would then be based on some "factor other than sex."

2. Proposals for a New Exception. If actuarial tables are to be exempted from Title VII's prohibition of disparate treatment, a new exception must be created. Proposals for such an exception have been based on the fact that longevity cannot be known in advance and therefore must be predicted, ${ }^{88}$ or on related ideas such as the nature of insurance. ${ }^{99}$ But these proposals must be rejected because they are inconsistent with the policies underlying Title VII and because they cannot be distinguished from suggestions that forbidden criteria be used to predict a wide range of other employment variables.

a. The Policies Underlying Title VII. Proponents of an exception must do more than merely point to some conceivable distinction between using sex to predict longevity and using sex to predict other employment variables such as weight-lifting ability. A legal distinction must remain consonant with the policies underlying the prohibition of disparate treatment.

Race, color, sex, religion, and national origin share three characteristics that justify the restrictions on their use. ${ }^{100}$ First, they

emphasized that its holding authorized efforts to "eliminate," "abolish," and "correct" "traditional patterns of racial segregation and hierarchy" and "conspicuous racial imbalance in traditionally segregated job categories." Id. at 204-09 (footnote omitted). See also B. Schlei \& P. Grossman, supra note 46, at 1199-1221 (collecting cases in which lower courts imposed quota remedies); id. at 332-33 (Supp. 1979) (same).

- See City of Los Angeles v. Manhart, 435 U.S. at 712-13; id. at 727 (Burger, C.J., concurring in part and dissenting in part).

97 See text and notes at notes 47-66 supra.

${ }^{98}$ City of Los Angeles v. Manhart, 435 U.S. 702, 728 (1978) (Burger, C.J., concurring in part and dissenting in part); Kimball, supra note 4, at 118-20.

29 TIAA-CREF Comments, supra note 3 , at 27.

${ }^{100}$ The legislative history of Title VII reflects the view that discrimination on the basis of forbidden criteria is especially unfair and morally reprehensible. The consensus was broader with respect to race than sex, but the majority included sex in the list of forbidden criteria. Scholars have undertaken to identify the reasons for the widespread view that discrimination on the basis of these criteria is especially suspect. That literature is now well 
are ascriptive ${ }^{101}$ and immutable. ${ }^{102}$ Second, they have been widely misused throughout history. ${ }^{103}$ Third, they are generally irrelevant to employment decisions. ${ }^{104}$ That is, race, color, sex, religion, and national origin are almost never of legitimate interest to an employer for their own sake; at most, these criteria are statistically associated with characteristics legitimately relevant to employment decisions, and the associations are generally thought to be rather weak. ${ }^{105}$

These characteristics of the forbidden criteria interact to make classifications based on them particularly offensive. Immutability gives rise to a special sense of unfairness, for the victim can never escape discrimination by her own efforts. Immutability also means that members of dominant groups are not restrained by the fear that they will some day become members of a minority group. ${ }^{108}$

The history of widespread discrimination aggravates the victims' inability to escape and imposes cumulative disadvantage on them. Moreover, persistent discrimination and the attitudes that underlie it stigmatize the victims and create resentment against any use of the criteria. Thus, even arguably legitimate uses may aggravate the cumulative disadvantage and impose the same painful sense of victimization, unfair treatment, and frustration.

The irrelevance of the forbidden criteria has two implications. Even when sex is strongly associated with a job qualification, at least some members of both sexes are qualified. And because the associations between forbidden criteria and job qualifications are generally weak, little predictive power is lost by telling employers

developed, and there is consensus concerning the elements of the explanation, although there are differences in emphasis. See, e.g., Brest, The Supreme Court, 1975 Term-Foreword: In Defense of the Anti-Discrimination Principle, 90 HARv. L. Rav. 1, 612 (1976); Fiss, A Theory of Fair Employment Laws, 38 U. CHI. L. REv. 235, 240-44 (1971); Underwood, supra note 5, at 1434-36.

${ }^{101}$ Ascriptive characteristics are those over which the individual has no control, usually because of the accident of birth.

${ }^{102}$ At least, they are immutable at any cost society is willing to coerce. It is no answer to tell people they may avoid further discrimination only by undergoing religious conversions, sex-change operations, or racial disguises. On the importance of immutability, see Brest, supra note 100, at 10; Fiss, supra note 100, at 241-43.

${ }^{10 s}$ See Brest, supra note 100 , at $7-8,10$; Fiss, supra note 100 , at 242 n.11.

10r See Brest, supra note 100, at 6-7, 10; Fiss, supra note 100, at 241.

108 If the statistical associations between forbidden and legitimate criteria were frequently strong, the argument against creating exceptions would be strengthened, because disparate treatment was forbidden despite these associations.

${ }^{108}$ Men are disadvantaged when segregated tables are applied to life insurance. Women, however, are clearly net losers when both life insurance and annuities are considered. See note 114 infra. 
not to use these criteria at all.

These characteristics of the forbidden criteria make all uses of them suspect and have led to the ban on even arguably legitimate uses. Consider the weight-lifting example. When an employer refuses to hire women because of their lower average weight-lifting ability, he may be acting neutrally and efficiently. It may be much more expensive to administer weight-lifting tests than to reject all women; ${ }^{107}$ the convenience of using sex may make up for its crudeness as a predictor. Such a defense would be difficult for a trier of fact to assess; the necessary economic data ${ }^{108}$ and the employer's actual motive would both be elusive. The employer might be maximizing wealth, indulging a taste for discrimination, or making a rough judgment about efficiency with either a predisposition to resolve uncertainties in favor of not hiring women or an insensitivity to the costs to women of not hiring them.

Even if the employer could demonstrate that he was pursuing his self-interest and not acting irrationally, the harmful consequences of using a forbidden criterion would remain. Women who could lift the weights but were forever denied the opportunity to demonstrate that ability would feel victimized, and the cumulative disadvantage imposed on such women would be increased. Both the psychic costs to the victims and the distributional consequences are irrelevant to the profit-maximizing employer, but quite relevant to the congressional policy against disparate treatment. ${ }^{109}$

There will always be a strong tendency to use forbidden criteria because they are convenient and cheap to administer. ${ }^{110}$ But

${ }^{107}$ Even a simple test such as lifting a stated weight a single time would cost something to administer. But a much more sophisticated test would be necessary. See Bowe v. ColgatePalmolive Co., 416 F.2d 711, 718 (7th Cir. 1969).

${ }^{108}$ A judge would need to know the cost of using some other predictor, the number of qualified workers erroneously excluded by each predictor, the number of unqualified workers erroneously hired because of each predictor, and the costs of each kind of error. Some of the costs would be indirect; for example, exclusion of qualified workers, at least in theory, should raise the employer's costs. See G. Becker, The Economics of Discrimination 39-42 (2d ed. 1971). The cost of such analysis would overwhelm the savings that are the primary advantage of using sex in the first place.

109 Psychic costs to the victim are a real cost, compensable in damages under some civil rights acts. See Carey v. Piphus, 435 U.S. 247, 260-64 (1978); B. SchleI \& P. Grossman, supra note 46 , at 1259 . Congress had redistributive goals for Title VII; it hoped that a policy of equal treatment of individuals would improve the economic lot of disadvantaged groups. See United Steelworkers v. Weber, 443 U.S. 193, 202-04 (1979).

${ }^{110}$ It has been suggested that the cost savings of using forbidden criteria as predictors may account for most discrimination in the United States today. See Phelps, The Statisti- 
because they are such crude predictors, the benefits of using them are outweighed by the costs to victims, the perceived unfairness of those costs, and the prophylactic advantages of eliminating a defense that would be easy to assert and difficult to litigate. ${ }^{111}$ Even Professor Posner, a leading proponent of free-market solutions, has concluded that efficiency cannot be allowed as a defense to a charge of disparate treatment. ${ }^{112}$

These reasons for forbidding classifications based on sex are fully applicable to insurance plans. Sex is still immutable; no woman can ever obtain the male rates, regardless of her own health or other indicators of life expectancy. Segregated annuity tables aggravate the cumulative disadvantage imposed on women, whose annuities are generally based on smaller lifetime earnings. ${ }^{113}$ Segregated life insurance tables do little to compensate. ${ }^{114}$ Segregated annuity tables also produce the frustration that results from discrimination based on an immutable characteristic.

There has also been a history of discrimination in insurance, however "discrimination" is defined. ${ }^{115}$ It is common for employers

cal Theory of Racism and Sexism, 62 AM. Econ. Rev. 659 (1972); Posner, The De Funis Case and the Constitutionality of Preferential Treatment of Racial Minorities, 1974 SuP. Cr. Rzv. 1, 9, 21; Stiglitz, Approaches to the Economics of Discrimination, 63 AM. Econ. Rev. Papers \& Proc. 287, $292-94$ (1973). See also D. Gordon, Theories of Poverty and UNDEREMPLOYMENT 46 (1972).

111 The Supreme Court has not been presented with an efficiency or administrativeconvenience defense to sex discrimination under Title VII. But it has rejected such defenses in equal protection cases. Wengler v. Druggists Mut. Ins. Co., $100 \mathrm{~S}$. Ct. 1540, 1545-47 (1980).

112 Posner, supra note 110, at 9-15. Professor Posner notes:

To say that discrimination is often a rational and efficient form of behavior is not to say that it is socially or ethically desirable. "Efficient" must never be confused with "good" or "right."

... [A] policy against hostile discrimination ... if it is to be effective, requires rejection of administrative convenience as a justification . . . .

Id. at 11,15 .

123 Women's periodic pension benefits have been about half those of men. See Lines, supra note 44, at 491; Thompson, Pension Coverage and Benefits, 1972: Findings from the Retirement History Study, Soc. SecurrTy Bull., Feb. 1978, at 3, 13.

11 An annuity can cost more than sixteen times as much as any other form of insurance benefit program. Hearings in the Matter of OFCC Sex Discrimination Guidelines, Section 60-20.3(c) Before the Employment Standards Administration of the Dept. of Labor (pt. 1) 155 (testimony of Robert $\mathrm{H}$. Duncan, Executive Vice-President of TIAA-CREF), quoted in Note, Sex Discrimination in Employee Fringe Benefits, 17 WM. \& MARY L. REv. 109, 131 n.133 (1975). See also text at notes 116-117 infra.

116 U.S. Comm'N on Civil Rights, Discrimination Against Minorities and Women in Pensions and Health, Life, and Disability Insurance (1978). For accounts of discrimination in the availability of coverage, see Bailey, Hutchison \& Narber, The Regulatory Chal- 
to pay men larger annuities because of their shorter life expectancy but simultaneously to require women to purchase life insurance at the same price as men. ${ }^{116}$ There is evidence that even where segregated tables are used for both life insurance and annuities, the annuity setback is inflated as compared to the life insurance setback, victimizing women with a more subtle double standard. ${ }^{117}$ This latter practice can be difficult to detect and prove. With the potential for such abuse, courts could never simply take the insurance industry's word concerning proper rates. If segregated tables were permitted, there would be complex trials on whether the difference in male and female rates was the precise amount justified by the shifting association between sex and mortality. ${ }^{118}$ Indeed, one author who thinks Manhart wrong in principle ultimately concludes that it is right because no other rule is workable. ${ }^{110}$

Finally, sex is irrelevant to longevity in the Title VII sense: it does not predict longevity in individual cases, and is a crude predictor even for groups. Both men and women die at all ages, over a

lenge in Life Insurance Classification, 25 Drake L. Rev. INS. L. ANn. 779, 796-98 (1976); Gillooly, The Developing Issue of Sex Discrimination in Insurance-An Overview, 23 AM. Life Ins. Counsel Proc. 261, 319-25 (1975).

116 See City of Los Angeles v. Manhart, 435 U.S. 702, 710 n.10 (1978); Key, supra note 5, at 21; Lines, supra note 44, at 489,521; Benefits, Perquisites and Special Services for Faculty Members of The University of Chicago 4-5 (1977) [hereinafter cited as BenEfiTs] (on file with The University of Chicago Law Review).

${ }^{117}$ It is common to use three-year setbacks for life insurance and six-year setbacks for annuities. Kimball, supra note 4, at 109. Since the difference in life expectancy as predicted by segregated tables is greatest at birth and gradually decreases with age, this is backwards. For example, at age 30 , a common age for buying life insurance, the difference in the United States in 1977 was 6.8 years; at age 65 , a common age to begin collecting an annuity, the difference was 4.4 years. 2 National Center for Health Statistics, Dep't of Health, Education \& Welfare, Vital Statistics of the United States, 1977, sec. 5, at 5-9 (1980). Insured lives are not so different as to reverse this relationship. $R$. DuncAN, TIAA Female MorTality EXPERIENCE 1965-1970 (1972) (on file with The University of Chicago Law Review); Society of Actuaries, 1973 Mortality Reports 225-27 (1973), reprinted in U.S. Comm'N on Civil Righrs, supra note 115, at 546-49; Metropolitan Life Ins. Co., Sex Differentials in Mortality, Statistical Bull., Aug. 1974, at 3, 4. Three-year life insurance setbacks have been criticized as inadequate even by some insurance companies. Gillooly, supra note 115 , at $326-27$.

118 Quite apart from any double standard, current tables probably overstate the female advantage in the generations currently working. See text and notes at notes 240-267 infra. Such claims would be fruitful ground for litigation unless the courts abdicated to the insurance industry and held that sexual equality need not be achieved with any precision for either groups or individuals. That such trials did not occur before Manhart is no basis for predicting that they would not occur if Manhart were overruled. Only if segregated tables were established in principle would litigators' attention turn to the details of their operation.

119 Rutherglen, supra note 4, at 248-56. 
range of more than one hundred years; the difference in expectation of life at birth is about eight years. ${ }^{\mathbf{1 2 0}}$ More than eighty percent of all female deaths can be matched with a contemporaneous male death. ${ }^{121}$ Thus, knowing a person's sex tells very little about when he will die-probably less than it tells about how much weight he can lift. ${ }^{122}$

The predictive power of sex is further diminished by the enormous variation in the association between sex and mortality over time, space, environment, and personal behavior. ${ }^{123}$ Insurance rates are calculated from mortality tables based on persons already dead, ${ }^{124}$ and charged to persons who will live far into the future. Thus there is no reason to expect sex differences among current insureds to match those reflected in the tables. ${ }^{125}$

Sex is also irrelevant in a related sense: much of the association between sex and mortality is spurious. That is, much of the association is accounted for by intervening variables, such as smoking or other self-destructive behavior. ${ }^{126}$ More men than women

120 Statistical Abstract, supra note 6, at 70.

121 Bergmann \& Gray, Equality in Retirement Benefits: The Need for Pension Reform, Crv. Rights Dig., Fall 1975, at 25, 25; Kimball, supra note 4, at 121.

122 Experts of the International Labor Organization have recommended weight-lifting limits for males that exceed those for females by $57 \%$ to $100 \%$. Bowe v. Colgate-Palmolive Co., 416 F.2d 711, 717-18 (7th Cir. 1969). Average differences in longevity are much smaller. See note 183 infra.

123 See part II infra.

124 See text and notes at notes 180-182 infra.

125 It might be argued that if sex is such a poor predictor, the competitive market would have long since eliminated its use. See Kimball, supra note 4, at 135-36 (semble). But the market has not even eliminated the most blatant form of discrimination, the use of segregated tables for annuities and integrated tables for life insurance. See text and note at note 116 supra. Such market failures are not surprising. Competition is dulled because it is enormously difficult for consumers to compare the terms, or even the prices, of annuity and life insurance contracts. The quoted rate is often a conservative guarantee, with the actual rate depending upon dividends or additional interest credited from time to time in light of experience. See Belth, Life Insurance Price Measurement, 57 Ky. L.J. 687, 705-10 (1969); Palmer, Illustrated and Realized Policyowner Dividends: An Empirical Analysis, $43 \mathrm{~J}$. RISK \& INs. 653 (1976). One commentator suggests that consumers' inability to compare products has contributed to a low rate of innovation in the insurance industry. Dorfman, The Theory and Practice of Innovation in the Private Insurance Industry: Comment, $45 \mathrm{~J}$. RISK \& INS. 689 (1978). In employer-sponsored insurance plans, the only ones subject to Title VII, competition is further dulled because the plan is selected by the employer, whose only incentive is to satisfy the majority of his employees at the least cost. If the majority of employees are male, the market incentive is to cater to them by selecting segregated annuity tables and integrated life insurance tables. See also Bergmann \& Gray, supra note 121, at 26.

${ }^{126}$ See text and notes at notes 243-251 infra. One scholar concluded: "[0]lder males in Western countries have only themselves to blame for a deteriorating mortality position." $\mathrm{S}$. 
tend to engage in such behavior, thus raising male death rates. But the explanatory variable is the behavior, not sex.

It might seem that spuriousness is unimportant, because if the difference in life expectancy at birth is eight years, we ought still to predict that any two individuals who were identical except for sex would have an eight-year difference in longevity. But this inference is statistically fallacious. This is most easily demonstrated where the association is wholly spurious, in which case we ought to predict identical longevity for two individuals who differ only by sex. The reason is that by choosing to compare these identical men and women, we have controlled for the true causal variables. Professor Kimball is therefore wrong when he argues that "[m]any a man would be glad to trade places [with women]. The probability of several extra years of life would be attractive to most men, even at cost of the tradeoff of longer life for smaller periodic benefits."127 A change of sex that is not accompanied by a change in any other variables will have no effect whatever on life expectancy unless sex, per se, has a causative role. Professor Kimball has made the classic mistake of confusing correlation with causation. ${ }^{128}$

Segregated tables are thus particularly offensive where, as here, we have reason to believe the association is largely spurious, although the basic statutory prohibition would apply even if this were not the case. This argument holds even in situations where the association is only partly spurious, because segregated insurance tables attribute the entire difference to sex. The unfairness is even more acute where, as here, the true causative variables are

Preston, Male Mortality and Cigarette Smoking 100 (Univ. of Cal. Population Monograph No. 7, 1970).

${ }^{127}$ Kimball, supra note 4, at 123. A similar fallacy apparently underlies Chief Justice Burger's otherwise incomprehensible argument that "categorizing people on the basis of sex ... is to take into account all of the unknown reasons, whether biologically or culturally based, or both, which give women a significantly greater life expectancy than men." City of Los Angeles v. Manhart, 435 U.S. 702, 727 (1978) (Burger, C.J., concurring in part and dissenting in part). This assumes that all of the real predictors of mortality affect every member of a sex equally, which is obviously not true.

${ }^{128}$ The mischief such confusion can cause is amply illustrated by a well known study of applications to University of California at Berkeley graduate schools. A higher percentage of male applications were successful. This seemed at first to be evidence of bias; on closer examination, however, the authors found that the reason for the differential was that men tended to apply to those departments that admitted a higher percentage of applicants. Bickel, Hammel \& O'Connell, Is There a Sex Bias in Graduate Admissions: Data from Berkeley, 187 ScIENCE 398 (1975). Just as with higher male mortality (where men steer themselves into high risk categories), women were directing themselves into high risk admissions pools. In both cases, people tend to the same erroneous conclusion: that it is sex, per se, that makes all the difference. 
self-induced destructive behavior, for no man need "trade places" with a woman in order to increase his longevity. Not only would that be pointless, as argued above, it would also be unnecessary, since the way to increase life expectancy is by not indulging in smoking or other self-destructive behavior. Under segregated actuarial tables, a man may enjoy a long life and receive larger periodic benefits at the same time, simply by not engaging in those activities that have caused other men to die prematurely. Women, obviously, do not have this option because their benefits are fixed at the lower female level.

Because the three characteristics that justify the ban on disparate treatment-immutability, irrelevance, and historic discrimination-are applicable in the context of actuarial tables, creation of an actuarial exception would run afoul of the fundamental principle underlying the statute.

b. The Argument from Necessity. Some proponents of segregated tables nevertheless argue that the statutory policy cannot sensibly be applied to employment criteria that must be predicted in advance and that cannot be measured directly. ${ }^{128}$ This too is a distinction without a difference. Mortality can be predicted by considering all humans as a single group, or by using a wide variety of unforbidden classifying criteria. ${ }^{130}$ Many of these predictors are

129 Kimball, supra note 4, at 118-20; King, supra note 9, at 557 .

sso Weight, physical build, physical condition, personal and family history, occupation, habits, aviation or military service, residence, and hobbies are commonly used in the sale of individual life insurance. S. HuEbner \& K. Black, Life Insurance 364-68 (9th ed. 1976). Some companies are now using smoking, exercise, and physical fitness. Kimball, supra note 4, at 119 n.96; Yenkel, Exercising to Ensure Health Can Save on Life Insurance, Chi. SunTimes, Sept. 4, 1979, at 41, col. 1. Mortality varies widely by marital status. M. CARTER \& P. Glick, Marriage and Divorce: A Social and Economic Study 340-42 (rev. ed. 1976); E. Kitagawa \& P. Hauser, Differential Mortality in the United States 105 (1973); Gove, Sex, Marital Status, and Mortality, 79 AM. J. Soc. 45 (1973). Mortality varies with most socioeconomic indicators including education, E. KITAGAwA \& P. HAUSER, supra, at 72, and occupation, id. at 34-46; Logan, Social Class Variations in Mortality, in Demographic ANalysis 138 (J. Spengler \& O. Duncan eds. 1956); Martin, A Comparison of Trends of Male and Female Mortality, 114 J. Royal Statistical Soc'y (Series A) 287, 297-98 (1951); Pressat, Surmortalité Biologique et Surmortalité Sociale, 14 Revue Françarse de SocioLOGIE (Numero Special) 103, 108-09 (1973). Geographic mortality differences in the United States are greater than sex mortality differences, see text and notes at notes 215-217 infra, as are marital status mortality differences among men, $R$. Retherford, The Changing Sex Differential in Mortality 91-93 (1975), and education mortality differences among women, E. Kiragawa \& P. Hauser, supra, at 16-17, 203-04. See also Anderson, supra note 34, at 5 . We express no opinion on whether these predictors should be used. Some may be good predictors; some may be too costly, or subject to policy objections, or based on spurious associations. It should also be noted that using all of these predictors in addition to sex would not legitimate the use of sex. No matter how many predictors were used, every sub- 
more expensive to use than sex, but so is a weight-lifting test; the difference, if there is one, is a matter of degree.

The use of sex as a predictor of longevity would be improper even if it were the only available predictor: sex would still be immutable, subject to abuse, and a weak predictor. Thus, courts have refused to allow the use of sex to predict immeasurable intangibles. In Diaz v. Pan American World Airways, Inc., ${ }^{131}$ for example, the court let stand findings that sex was the best single predictor of ability to satisfy passengers' emotional needs on airplane flights, and that there was no way to measure this ability directly. Even so, Pan Am's policy of hiring only women was held to be illegal disparate treatment.

Any other rule would seriously weaken the statute, for many job skills cannot be measured directly or predicted reliably, especially for new entrants to the labor force. Indeed, much of the work of industrial psychology is devoted to predicting and evaluating job qualifications, and for complex jobs the problems of evaluating even incumbents are enormously difficult. ${ }^{\mathbf{1 3 2}}$ No hiring officer can consistently predict absenteeism, turnover, persistence, reliability, creative genius, courage, or judgment with much accuracy in individual cases, and employers may frequently be able to adduce some evidence that these traits have statistical associations with sex or race. ${ }^{133}$ Such defenses would be easy to assert and difficult to litigate. Most important, such defenses would violate the fundamental principles of the Act, by permitting employers to penalize, solely because of their sex, individuals for whom the prediction is inaccurate.

A variation of the necessity argument is that insurance pools must take account of known differences in risk to the extent justified by the cost of doing so, and that failure to do so creates subsidies between groups, followed by efforts to withdraw from the pool and consequent inefficiencies. ${ }^{134}$ At most, this is a special case of

category would include persons who differed only by sex.

131442 F.2d 385 (5th Cir. 1971).

${ }^{132}$ Lerner, supra note 80 , at 279-92.

13s The authoritative work on sex differences is E. Maccoby \& C. JackuIN, The PsyCHOLOGY of Sex DifFerences (1974). They found that many popular beliefs about sex differences have "little or no basis in fact." Id. at 355. But on almost every point there are conflicting studies on which an employer could rely, and with respect to some variables, the weight of the evidence points to associations with sex. See id. at 162-63, 227-74, 349-74.

136 See Kimball, supra note 4, at 106-08, 134-35; Rothschild \& Stiglitz, Equilibrium in Competitive Insurance Markets: An Essay on the Economics of Imperfect Information, 90 Q.J. EcoN. 629 (1976). 
the argument that sex discrimination is sometimes economically efficient. The efficiency results, if at all, from the same facts that make sex an arguably efficient predictor in other contexts: that it has a little predictive power and is almost costless to use. That justification for disparate treatment is no more acceptable in the insurance context than in any other. ${ }^{135}$

Nor are the possible inefficiencies particularly intolerable in the insurance industry. Very few employer-sponsored insurance plans use any predictors other than age and sex; ${ }^{188}$ most do not use sex, ${ }^{137}$ and some do not even use age. ${ }^{138}$ All other predictors are ignored, and the resulting inter-group subsidies tolerated, because using the predictor costs more than it is worth, ${ }^{139}$ is socially unacceptable, ${ }^{140}$ or is illegal. ${ }^{141}$ Ignoring these predictors has not, however, produced an exodus of participants from these pools, because there are so many advantages to staying in, ${ }^{142}$ there are restrictions on withdrawal, ${ }^{143}$ and perhaps for other reasons. ${ }^{144}$ There is little reason to expect that greater problems will result from full enforcement of the ban on sex as a predictor. ${ }^{145}$

185 See text and notes at notes 107-112 supra.

136 See Anderson, supra note 34, at 5, 7; Key, supra note 5, at 12; Kimball, supra note 4, at 107-08, 118-20; King, supra note 9, at 565 .

13743 Fed. Reg. 38,029, 38,030 (1978) (reporting findings of hearings held by Department of Labor in 1974).

138 See, e.g., BenErrrs, supra note 116 , at $4-5$.

139 See Kimball, supra note 4, at 107-09, 119-20.

140 See Risk Classification, supra note 33, at 20-21.

141 See Bailey, Hutchison \& Narber, supra note 115, at 793-801; Gordon, The AntiDiscrimination Laws-A Survey of the Development and Enforcement-1900-1950, 1950 Am. Life Convention Legal Section Proc. 34, 37-38, 47; Kimball, The Purpose of Insurance Regulation: A Preliminary Inquiry in the Theory of Insurance Law, 45 MrNo. L. REv. 471, 496 (1961).

142 Savings in administrative costs, tax benefits, rights to transfer annuity contracts from one employer to another, the need for the highest possible current income, the need to provide for survivors, or a general preference to avoid or accept risk may outweigh the desire to play the statistical odds on mortality in selection of plans and payment options. See Key, supra note 5, at 20-25.

163 Participation in employer-sponsored plans is often mandatory. There are tax disadvantages to lump sum settlements, and some plans preclude them-for example, TIAACREF (contract on file with The University of Chicago Law Review).

144 Some insureds may be unaware of the associations between mortality and their personal characteristics. Some may put little faith in statistical generalizations, or think themselves immune from the odds.

145 Some of the predictors not currently used make as big an apparent difference as sex, see note 130 supra, although the associations are not as well known. Even Professor Kimball acknowledges that sexually integrated tables involve few technical problems when used voluntarily. Kimball, supra note 4 , at 133 . But he claims that making integrated tables mandatory creates incentives not to hire women, variations in the rate for the pool if its 
c. The Competing Analogies of Race and Age. Another way to consider the proposed actuarial exception to Title VII is to examine the treatment of analogous predictors of mortality. The majority in Manhart analogized sex to race. ${ }^{146}$ There is near consensus that race should not be used as a predictor in insurance, ${ }^{147}$ and many state insurance laws ban its use. ${ }^{148}$ In contrast, some proponents of segregated tables analogize sex to age; there is consensus that age can be used to predict mortality. ${ }^{149}$

Congress plainly has decided that sex is more like race. Except for some differences in defenses ${ }^{150}$ and a separate section on pregnancy, ${ }^{151}$ racial and sexual discrimination are forbidden in identical terms in the same clause of the same statute. Those who argue for different meanings of "discriminate" on the basis of race and on the basis of sex are quarrelling with the statute, not interpret-

sexual composition changes, and incentives for men to elect settlements or guarantees and women to elect annuities. Id. at 133-35. See also King, supra note 9, at 562-63. But all of these problems - to the extent they are problems-would be equally true of voluntarily integrated plans; Professor Kimball does not explain why making integration mandatory would aggravate them. His projections about what might happen under integrated tables are less credible than his concession that integrated tables have worked, Kimball, supra note 4, at 133. See also City of Los Angeles v. Manhart, 435 U.S. 702, 716 n.30. Professor Kimball also predicts that employers with a largely male work force will withdraw from multi-employer pools, so that ultimately, portability will be lost to the "immense disadvantage" of both men and women. Kimball, supra note 4, at 134-35. But it is precisely the immense disadvantage of losing portability that makes it unlikely to occur. See Key, supra note 5, at 20-25. Some members of the insurance community agree that integrated tables will work. See MASSACHUSETts Division of Insurance, Automobile Insurance Risk Classifications: Equity and AcCURACY 144-205 (1978); Anderson, supra note 34, at 7; Kent, Sex and Other Underwriting Discriminations, Life INs. Selling, Mar. 1979, at 6.

146435 U.S. at 709.

247 See Risk Classification, supra note 33, at 21; Kimball, supra note 141, at 496; Kimball, supra note 4, at 111-13; Randall, Risk Classification and Actuarial Tables as They Affect Insurance Pricing for Women and Minorities, in U.S. Comm'N on Civil RIGHTs, supra note 115, at 527, 535-36, 607-08; Van Alstyne, supra note 5, at 150. For dissenting views, see American Academy of Actuaries, Report on Task Force on Risk ClassificaTION (1977), reprinted in U.S. CoMm'N oN CIviL RIGHTs, supra note 115, at 577, 590-91; Bailey, Hutchison \& Narber, supra note 115, at 793 n.54. Not all of those who think that race should not be used necessarily think that Title VII forbids its use. But they must at least think that Title VII does not require its use.

${ }^{148}$ Authorities cited note 141 supra.

140 Hedges, supra note 9, at 143; Kimball, supra note 4, at 123; King, supra note 9, at 558-60; Myers, supra note 9, at 145.

150 There is no BFOQ defense to race discrimination. 42 U.S.C. \& 2000e-2(e) (1976). The Bennett amendment, which incorporates the Equal Pay Act's provision that disparate impact in compensation is not illegal, does not apply to race. 29 U.S.C. $\$ 206$ (d)(1) (1976); 42 U.S.C. $\S 2000 \mathrm{e}-2(\mathrm{~h})(1976)$.

15142 U.S.C. $\S 2000 \mathrm{e}(\mathrm{k})$ (Supp. II 1978). 
ing it. ${ }^{152}$ Age, on the other hand, was excluded from Title VII for fear that group insurance plans would be disrupted, ${ }^{153}$ and later included in a much less sweeping ${ }^{154}$ separate statute that specifically exempts insurance plans. ${ }^{155}$

These congressional choices are sound, given the policies underlying discrimination law. Age does not fully share with race and sex the characteristics that make the latter types of discrimination so offensive. Most individuals can control when they buy life insurance or begin collecting an annuity; no one can control his race or sex. Age discrimination arguably has been less pervasive and unidirectional than sex discrimination: sometimes the young are discriminated against and sometimes the old. ${ }^{186}$ Finally, the association between age and mortality is much stronger than that between sex and mortality. After early childhood, age-specific death rates increase almost uniformly with age until they approach one; ${ }^{157}$ put another way, each year of life uses up a year of the maximum human life span.

The analogy between sex and race is much stronger. Three arguments have been offered to distinguish the two. First, it has been suggested that blacks have been more abused than women. ${ }^{158} \mathrm{We}$

${ }^{182}$ The stock counter-example is segregated restrooms, but the different treatment of race and sex with respect to restrooms results from a difference in facts rather than a different construction of the statute. Separate but equal facilities are discriminatory only if the segregation stigmatizes. See Brown v. Board of Educ., 347 U.S. 483 (1954) (interpreting the constitutional guarantee of equal protection); J. Ely, Democracy and Distrust 150 (1980). Racially segregated restrooms stigmatize blacks, but sexually segregated restrooms stigmatize no one. See also text and notes at notes 88-91 supra.

18s See 110 Cong. REc. 13490-92 (1964).

154 The Age Discrimination in Employment Act, 29 U.S.C. §§ 621-634 (1976 \& Supp. II 1978) ("ADEA"), is fundamentally different from Title VII. Title VII generally forbids racial, sexual, religious, and ethnic classifications. The ADEA forbids only some age classifications, and actually makes one of its own: workers are protected only between the ages of 40 and 70. 29 U.S.C. \& 631(a) (Supp. II 1978).

${ }^{285} 29$ U.S.C. $\S 623(f)(2)(1976)$.

1se The disabilities of youth, such as those with respect to voting, driving, drinking, and contracting, are a form of age discrimination, widely thought to be justifiable. The unemployment and underemployment rates among young workers have far exceeded the rates among older workers protected by the Age Discrimination in Employment Act; discrimination against older workers did not produce cumulative disadvantage comparable to that reflected in such rates for women and blacks. See T. Sullivan, Marginal Workers, MarGINAL JoBs 75-79, 84-85, 96-97, 103, 106-07 (1978).

${ }^{157}$ There is currently a small "bulge" in the age-specific mortality rates of young men in their early twenties, but this bulge can be removed by controlling for violent deaths and motor vehicle accidents. Bayo, Discussion of Preceding Paper, 28 Transacrions Soc'y AcTUARIES 117 (1976).

1ss Regents of the Univ. of Cal. v. Bakke, 438 U.S. 265, 303 (1978) (opinion of Powell, 
find that unpersuasive. ${ }^{159}$ More importantly, the claim that women have been so much less victimized that sex discrimination deserves more tolerance calls for a classically political judgment, and Congress has rejected the claim. ${ }^{160}$

The second proffered distinction between race and sex is that it is more difficult to classify by race. ${ }^{161}$ Yet insurers did use racesegregated tables until the practice was banned, ${ }^{162}$ and a careful study of data quality has found that racial identification is not a problem in mortality research. ${ }^{163}$ Apart from its implausibility, the argument is not responsive to the reasons for banning disparate treatment; efficiency is not a defense. ${ }^{164}$

Finally, it has been suggested that the association between race and mortality is environmental or social, but that that between sex and mortality is genetic. ${ }^{185}$ Even if the claim were true, no one has plausibly explained why it justifies using sex as a predictor: women are shorter than men for what are probably genetic

J.); Kimball, supra note 4, at 113 n.82; Rutherglen, supra note 4, at 205-12.

${ }^{159}$ In employment, the focus of Title VII, women have fared worse than blacks in some ways and better in others. Black men are more likely to be unemployed than white women, Statistical ABSTRact, supra note 6, at 396, but they are much better paid when they work. Among full-time year-round workers, the median earnings of white women are only $\$ 9,732$, compared to $\$ 12,530$ for black men and $\$ 16,360$ for white men. Black women earn least of all, with a median of $\$ 9,020$. U.S. Bureau of the Census, Current Population Reports Series P-60, No. 120, Money Income and Poverty Status of Families and Persons in the UnIted States: 1978 (ADVANCE REPORT) 18-19 (1979). Work patterns and levels of job qualification do not explain the earnings differential; in fact, employed women have substantially more education than employed blacks. Statistical ABSTRACT, supra note 6, at 398. At equivalent levels of education, both black and white women earn less than black men. U.S. Comm'N on Civil Rights, Social Indicators of EQuality for Minorities and Women 22-24 (1978). Even when occupational prestige, age, weeks worked, hours worked last week, and average income in the state of residence are controlled in addition to education, the earnings predicted in a regression equation show a comparable gap between black men and black or white women, $i d$. at 53-54. The rate of return to education is also lower for all women and for career women, as compared to black men. Suter \& Miller, Income Differences Between Men and Career Women, 78 AM. J. Soc. 962, 970-71 (1973).

${ }^{160}$ Congress chose to treat sexual and racial discrimination identically in 1964 , and a congressional committee spoke directly to the issue during consideration of the 1972 amendments to Title VII. H.R. REP. No. 238, 92d Cong., 1st Sess. 5 (1971), reprinted in [1972] U.S. Code Cong. \& AD. News 2137, 2141.

${ }_{161}$ Kimball, supra note 4, at 111-13.

${ }_{162}$ See J. MAGEe, Life InsuRAnce 522 (rev. ed. 1951).

163 E. Kitagawa \& P. Hauser, supra note 130 , at 95.

${ }^{164}$ See text and notes at notes 107-112 supra. Professor Kimball has argued that "fundamental moral notions about equal treatment of the races" preclude taking race into account. Kimball, supra note 141 , at 496 . Such fundamental moral notions do not depend on difficulties of classification.

${ }^{265}$ Kimball, supra note 4, at 111-13. See AmErican ACADEmy of ACTUARIES, supra note 147, at 590-91; Kimball, supra note 141, at 496; Randall, supra note 147, at 535-37. 
reasons. Regardless of its causes, the association between sex and mortality is weak and unstable; calling the association genetic does not make sex a better predictor. ${ }^{166}$ In any event, those who would recognize a genetic-difference exception to the ban on disparate treatment must bear the burden of proving that the difference is really genetic. In fact, the claim that sex differences in mortality are largely explained by genetic differences is simply wrong.

\section{The Demographic Analysis}

Legal scholars on both sides of the Manhart controversy are inclined to assume that permanently lower female mortality is a simple fact: women live longer than men. ${ }^{167}$ The exact difference cited varies from five to ten years. ${ }^{168}$ Such writers suggest- explicitly or implicitly-that this difference is stable and will remain true for the present generation of insureds. ${ }^{169}$ Some proponents of segregated tables go even further, claiming that sex mortality differences ("SMDs") are nearly universal, and largely genetic in

${ }^{168}$ It has been suggested that if sex mortality differences are genetic, sex itself is actually a predictor of mortality and not just a surrogate for the true factors, Kimball, supra note 4 , at 112 , and that sex can therefore be used as a predictor under such circumstances without indulging a sexual stereotype, Halperin \& Gross, Sex Discrimination and Pensions: Are We Moving Towards Unisex Tables?, in Proceedings of New York University 30tr annual National Conference on Labor 235, 249 (R. Adelman ed. 1977). A similar position is taken in Kimball, supra note 141, at 496 . But this is demonstrably not true. One known genetic difference between the sexes, related to mortality, is that males are far more likely than females to be hemophiliacs. But only a few males are at risk, only some of those actually have the disease, and these individuals can be identified. Thus, sex is not the "true factor" in shortened life from hemophilia, and to treat all males as hemophiliacs would be a "sexual stereotype," even though hemophilia is a sex-linked genetic trait. To claim that sex itself is a predictor of mortality, and not merely a surrogate, proponents of segregated tables must explore each genetic or biological difference and show that it affects all members of a sex and is not merely associated with sex. Even if some genetic or biological factor were shown to affect every member of a sex, it would do so only marginally; sex still would not predict longevity for individuals, and would still predict weakly for groups.

${ }_{167}$ See, e.g., City of Los Angeles v. Manhart, 435 U.S. 702, 704 (1978); id. at 724 (Blackmun, J., concurring); id. at 726 (Burger, C.J., concurring in part and dissenting in part); Bailey, Hutchison \& Narber, supra note 115, at 787; Bernstein \& Williams, supra note 44, at 1203; Gerber, supra note 9, at 1218, 1230; Gold, supra note 44, at 597 \& n.5; Gold, Of Giving and Taking: Applications and Implications of City of Los Angeles, Department of Water and Power v. Manhart, 65 VA. L. REv. 663, 699 (1979).

${ }^{188}$ See, e.g., Sowell, Status Versus Behavior, 1979 WASH. U. L.Q. 179, 180 (ten years); Comment, Equal Protection, Title VII, and Sex-Based Mortality Tables, 13 TuLSA L.J. 338, 341 (1977) (five years); Note, supra note 114, at 130 (seven years).

${ }^{168}$ See, e.g., Bernstein \& Williams, supra note 44, at 1207; Kimball, supra note 4, at 113. 
origin. ${ }^{170}$

Even if true, these claims would not change our view of the statute. ${ }^{171}$ But they are crucial to the conclusions of some proponents of segregated tables. The importance of these claims is stated most clearly and forcefully by Professor Kimball. He writes that racial mortality differences are social and environmental rather than genetic: "Thus, mortality tables based on a race classification will reflect accurately only past experience under social conditions now in rapid flux. They have little predictive value for new conditions. Race is only an inaccurate surrogate for the true factors and has no demonstrable effect in itself."172 By contrast, he argues that SMDs are primarily biological, and, by implication, important in themselves and useful for predicting the future. ${ }^{173} \mathrm{His}$ evidence for the genetic origin of SMDs is that "better female mortality experience is an almost universal phenomenon."174

In fact, the female advantage is not "almost universal." The present female advantage in the United States is largely explained by environmental and behavioral factors that are subject to rapid change- -so much so that SMDs have varied even more than racial mortality differences. ${ }^{175}$ Thus, consistency requires the admission that sex, like race, is "wholly indefensible on factual grounds" as a predictor of mortality. ${ }^{178}$

This conclusion is so contrary to the conventional wisdom in

170 Gerber, supra note 9, at 1218-21; Gillooly, supra note 115, at 326; Hedges, supra note 9, at 144; Kimball, supra note 4, at 113; Randall, supra note 147, at 536-37.

171 See text and note at note 166 supra.

172 Kimball, supra note 4, at 112. Similar arguments are made by Gerber, supra note 9 , at 1218-20; Randall, supra note 147, at 535-37.

${ }^{173}$ Kimball, supra note 4, at 112-13.

174 Id. at 113 n.81.

178 From 1920 to 1970 , the SMD at birth in the United States increased 6.7 years or $670 \%$, while the difference at birth between whites and nonwhites declined 3.2 years or 36\%. Statistical ABstract, supra note 6, at 70. Controlling for education, E. Kitagawa \& P. HAUSER, supra note 130 , at 167 , or occupation, Bailey, Hutchison \& Narber, supra note 115 , at 793 n.54, does not eliminate the excess mortality recorded for blacks. The greater reported life expectancy of elderly blacks, noted by Kimball, supra note 4, at 112, and Lines, supra note 44 , at $523 \mathrm{n} .131$, is thought to be an artifact of inaccurate and inadequate data. E. Kitagawa \& P. Hauser, supra note 130, at 93-98; M. Spiegelman, Introduction to Demography 63-65 (rev. ed. 1968); Bogue, Misra \& Dandekar, A New Estimate of the Negro Population and Negro Vital Rates in the United States, 1930-1960, 1 Demography 339, 354 (1964); Myers, Errors and Bias in the Reporting of Ages in Census Data, 41 Transactions Actuarial Soc'y Am. 395, 399-400 (1940); Rosenwaike, A New Evaluation of United States Census Data on the Extreme Aged, 16 Demography 279, 286-87 (1979); Rosenwaike, On Measuring the Extreme Aged in the Population, 63 J. Am. Statistical A. 29, 40 (1968).

${ }^{178}$ Kimball, supra note 4, at 113. 
the legal and insurance literature that it is likely to be greeted with skepticism. But most empirical research on SMDs has been done in other disciplines, and all major investigators now believe that social, cultural, environmental, and behavioral factors are more important than genetic or biological factors in explaining SMDs. ${ }^{177}$ We have synthesized this work, along with other sources of evidence, and the strength of the resulting conclusion may surprise even some demographers. But for the most part, we are simply reporting to the legal profession the existing literature on SMDs.

\section{A. A Note on the Evidence}

Two common mortality measures, the expectation of life and the survival rate, are derived from an actuarial table called a life table. The most commonly used table is a period or current life table, which is based on a hypothetical cohort of babies, usually 100,000 . It is assumed that all the babies were born alive at the same instant and were subjected throughout their lives to the agespecific death rates actually observed in the general population during a short period of time. ${ }^{178}$ A 1980 period life table assumes that babies born in 1980 will be subject to the 1980 mortality rates for infants, and that when they are aged 20 (in 2000), they will be subject to the mortality rates that affected 20 -year-olds in 1980 , and so on. A statement that the expectation of life at birth in 1980 is 73 years means that the average remaining life time for all 100,000 babies would be 73 years. A statement that the survival rate between ages 0 and 73 is .60 means that $60 \%$ of the 100,000 babies would survive to exact age 73 , if the 1980 mortality conditions persisted unchanged. ${ }^{179}$

The life table cannot be constructed until age-specific death rates have been computed. ${ }^{180}$ In practice, these rates are compiled

177 S. Preston, supra note 126, at 100; R. Retherrord, supra note 130, at 101; Enterline, Causes of Death Responsible for Recent Increases in Sex Mortality Differentials in the United States, 39 Milbank Memorial Fund Q. 312, 325 (1961); Pressat, supra note 130, at 105; Waldron, Why Do Women Live Longer than Men?, 10 Soc. Scl. \& MzD. 349, 349 (1976).

178 See generally N. Keyfitz, Introduction to the Mathematics of Population 3-19 (1968); 1 H. Shryock \& J. Siegel, Methods and Materials of Demography 429-61 (2d printing 1973).

170 These illustrations are close to current U.S. experience; the data are those actually reported for 1977. 2 National Center por Health Statistics, supra note 117, sec. 5, at 5$9,5-12$. The life table survival rate is computed as the ratio of persons alive at age $(x+n)$ to the number alive at age $x$.

${ }^{180}$ Some legal commentators are confused on this point. See Comment, supra note 168, 
by classifying death registrations by age at death and relating them to the census population or estimated population of the same age in the same year. ${ }^{181}$ The rates are converted into the probability that a person reaching exact age $x$ will not live to exact age $(x+n)$.

What is common to both life table measures and death rates is that they are based on the experience of persons already dead, with the assumption that these recent death data are an adequate guide to the future. Because of the long-term trend of declining mortality, life tables nearly always underestimate longevity and age-specific death rates nearly always overestimate future mortality. SMDs are computed by comparing survival rates or life expectancies compiled separately for each sex; ${ }^{182}$ the stated difference depends on the measure that is used..$^{183}$

\section{B. The Evidence for a Universal, Biological, Female Advantage}

The primary evidence for the genetic origin of SMDs is the claim that lower female mortality is almost universal. As Professor Kimball summarizes: "Women have better mortality experience than do men, at all ages from conception on, at all times during

at 339. The numerator of an age-specific death rate is deaths to persons aged $x$; the denominator is persons aged $x$ in the population.

182 Many countries compile mortality data at long or irregular intervals. Thus, reliance on scattered dates below does not mean that there are contrary data from other years.

${ }_{182}$ Whenever sufficient data are available, demographers prefer to use sex-specific life tables for technical reasons, but this does not imply that integrated tables are invalid. The quality of the age data on which life tables are based is likely to differ by sex. See 1 U.S. Bureau of the Census, United States Census of Population: 1960, Characteristics of the Population, Part 1, United States Summary xxxix (1964); Siegel, Estimates of Coverage of the Population by Sex, Race, and Age in the 1970 Census, 11 Demography 1 (1974); Zelnick, Errors in the 1960 Census Enumeration of Native Whites, 59 J. AM. Statistical Ass'N 437 (1964). Estimates of the net reproduction rate require life table survival rates for females only; other techniques require viewing the two sexes as if they were two populations interacting, and this requires sex-specific tables. N. KEYFiTZ, supra note 178, at 293-308; 1 H. ShrYocK \& J. StEgel, supra note 178, at 525-26. The study of SMDs, an important area of mortality research, obviously requires data classified by sex. For a recent review, see Kitagawa, On Mortality, 14 Demography 381, 384 (1977).

${ }^{103}$ The importance of the SMD can be magnified or diminished by the choice of mortality measure, as the following table shows: 
this century, in almost all countries."184 Although it is true that greater female longevity has been common in recent times, these generalizations have too many exceptions to support an assertion that SMDs are biologically or genetically based. We will consider these generalizations in turn, and then review other variations in SMDs.

1. "At All Ages from Conception on." The conventional wisdom, even in demography textbooks, ${ }^{185}$ has been that women have lower death rates than men at all ages. A thorough review of the literature, however, reveals important exceptions to this generalization.

Early studies of aborted fetuses seemed to indicate that prenatal mortality was much higher for males than for females, and that the earliest fetal deaths were the most disproportionately male. This led to speculation that many more boys than girls were conceived. Later investigators, armed with better techniques for identifying fetal sex, concluded that "no excess mortality of males during the previable period could be demonstrated."188 Thus the evidence is inconsistent with the claim of female advantage "from

Male-Female Differences in Some Common MortaltTy Measures, 1969-1971

\begin{tabular}{|c|c|c|c|}
\hline & Male & Female & Difference \\
\hline $\begin{array}{c}\text { Expectation of life }\left(\stackrel{\circ}{\mathbf{e}}_{\mathbf{x}}\right) \\
\text { at birth }\left(\stackrel{\circ}{0}_{0}\right) \\
\text { at age } 1\left(\stackrel{\circ}{e}_{1}\right) \\
\text { at age } 65\left(\stackrel{\circ}{65}_{6}\right)\end{array}$ & $\begin{array}{l}67.04 \\
67.58 \\
12.99\end{array}$ & $\begin{array}{l}74.64 \\
74.97 \\
16.83\end{array}$ & $\begin{array}{l}7.60 \\
7.39 \\
3.84\end{array}$ \\
\hline Median age at death ${ }^{\mathbf{a}}$ & 71.87 & 79.88 & 8.01 \\
\hline Survival rate to age $\mathbf{5 0}$ & $86.1 \%$ & $91.9 \%$ & $5.8 \%$ \\
\hline Survival rate to age 65 & $64.3 \%$ & $79.7 \%$ & $15.4 \%$ \\
\hline Crude death rate $b$ & $10.9 / 1000$ & $8.1 / 1000$ & $2.8 / 1000$ \\
\hline
\end{tabular}

Source: Taken or calculated from Statistical ABSTRACT, supra note 6; 1 U.S. Public Health Service, Dep't of Health, Education \& Welfare, United States Life TABLES, 1969-71 No. 4 (1975).

The age at which one-half of the life table cohort of 100,000 babies would be dead.

b The weighted average of age-specific death rates, customarily reported as number of deaths per 1000. at 1220.

${ }^{144}$ Kimball, supra note 4, at 113 (emphasis in original). Accord, Gerber, supra note 9,

183 E.g., W. Petersen, Population 67, 223 (3d ed. 1975).

188 Tietze, $A$ Note on the Sex Ratio of Abortions, 20 Human Brology 156, 159 (1948). 
conception on."187

Except for societies that practice female infanticide, either directly or through neglect, ${ }^{188}$ it appears that death rates in the first year of life are higher for males. ${ }^{189}$ Given the nearly universal preference for sons, ${ }^{180}$ this mortality differential flies in the face of probable social and cultural efforts to stem it, and may therefore reflect a biological or genetic predisposition.

After the age of one year, higher female mortality was once believed to exist only during the childbearing years in countries with high fertility and high infant and maternal mortality. ${ }^{101}$ More recent studies dispute this. In his comprehensive review of the data, Professor Stolnitz concluded:

The occurrence of higher male survival rates at some ages, far from being comparatively rare, has in fact been usual over the world during most of the last century. Indeed, for the decades before 1920, the stronger statement seems justified that such rates were also usual within each major region. Thus in the West lower female mortality at all ages first became typical as recently as the 1930's. ${ }^{192}$

Higher female mortality was common not only in the reproductive years, but in early and late childhood as well. ${ }^{18 s}$

Professor Preston extended the Stolnitz research. He found

${ }_{187}$ These studies are reviewed by R. Retherford, Analysis of Trends in Sex Mortality Differentials in Developed Countries 13 (1970) (Ph.D. dissertation, Sociology, University of California at Berkeley). See also Waldron, supra note 177, at 349.

188 Female infanticide was practiced in Western Europe until about 1850. T. McKeown, The Modern Rise of Population 47, 146-47 (1976); S. Preston, Mortality Patterns in National Populations 147-48 (1976); Langer, Infanticide: A Historical Survey, 2 Hist. ChILdhood Q. 353 (1974).

188 S. Preston, supra note 188, at 121. But a U.S. Census Bureau analysis found higher female infant mortality rates for India in 1969. U.S. Bureau of THE Census, Country Demographic Profiles: India, ISP-DP-16, at Table 5 (1978) [hereinafter cited as IndiA Profile].

190 N. Williamson, Sons or Daughters: A Cross-Cultural Survey of Parental PrefERENCES 103 (1976).

191 L. Dublin, A. LotKa, \& M. Spiegelman, Length of Life 129 (rev. ed. 1949).

192 Stolnitz, A Century of International Mortality Trends II, 10 Population Stud. 17, 23 (1956). Since 1930, even in the West, female death rates exceeded those of men in the following age groups: ages 1-4, 10-19, Italy, 1931, S. Preston, N. KeYfitz \& R. Schoen, Causes of Death: Life Tables for National Populations 404-07 (1972); ages 25-54, Netherlands, 1931, id. at 460-63; ages 10-19, Portugal, 1930, id. at 580-83; ages 10-14, Scotland, 1951, id. at 604-07; ages 10-14, Spain, 1930, id. at 640-43; ages 15-19, Sweden, 1930, id. at 660-63; ages 10-14, Sweden, 1940, id. at 664-67; ages 15-19, Switzerland, 1930, id. at 68083.

${ }^{193}$ Stolnitz, supra note 192, at 24. 
that higher female mortality for various age groups occurred more frequently in those countries with the highest overall mortality. Even in the countries with the lowest mortality, over $10 \%$ of the age-cause-specific categories showed higher female than male mortality. The age categories were concentrated in the childbearing years, but deaths related to childbirth do not explain the finding: neoplasms were the leading cause of higher female mortality. ${ }^{194}$

Professor Retherford, in examining age-specific death rates in the United States for 1910 and 1965, found that male-female differences declined sharply below the age of 5 , remained static at ages 5-49, and increased sharply above age 50 . This suggests that virtually all of the increased differential in the U.S.-from 1 to 7.7 years since 1920 -has occurred at age 50 and older. ${ }^{195}$

2. "At All Times During This Century." There is evidence that greater female longevity is a relatively recent phenomenon. Analysis of Paleolithic, Mesolithic, and Neolithic burials, as well as analysis of burials and historical records for the Roman Empire and medieval Europe, indicates that before the modern era men outlived women. ${ }^{198}$ Professor Stolnitz found that greater female longevity among national populations became general in the West only in the 1930s, and in non-Western Europe a half-decade later. ${ }^{107}$ Before World War I, higher male life expectancy at some ages might have been fairly frequent in non-Western Europe; examples include Italy, Austria, Malta, Bulgaria, and possibly Hungary. ${ }^{198}$ Greater male longevity has persisted to the present in

194 S. Preston, supra note 188, at 121-23. Neoplasms include tumors and many forms of cancer. The age-cause-specific categories are created by cross-classifying age groups by major causes of death.

193 R. RETHERFoRD, supra note 187, at 4. In a later decomposition, he specifies the age group more precisely as 60-79. Id. at 28 . See also S. PRESToN, supra note 188, at 36 . Decomposition techniques rely on the fact that any population may be subdivided further into constituent groups. A rate for that population may be thought of as the weighted average of the rates for each of the groups. The population rate may be separated into components due to the constituent rates, to the weights (or composition) of the constituent groups, and sometimes to an interaction of rates and weights. For example, an SMD may increase because male death rates increase, because female death rates decrease, or because the age composition of either males or females has changed, putting more persons in the older age categories where death rates are higher. A decomposition technique can show which of these causes is operating.

${ }^{206}$ A number of such studies are cited in G. Acsadi \& J. Nemeskeri, History of Human Life Span and Mortality 182-259 (1970). Acsadi and Nemeskeri are careful to note the shortcomings of their data and the critiques made of them. The data are suggestive but not conclusive.

107 Stolnitz, supra note 192, at 24-25.

${ }^{108}$ Id. at 24-25. There were exceptions in non-Western Europe after 1935; for example, 
parts of Asia, Africa, and Latin America. ${ }^{199}$ Even in the United States, greater female longevity has not been universal in the twentieth century. ${ }^{200}$

The recency of greater female longevity is inconsistent with claims that the phenomenon is biological or genetic. In evolutionary terms, a few centuries is an extremely short time.

3. "In Almost All Countries." The statement that female mortality is lower in "almost all countries" of the world is true only if we ignore the $73 \%$ of the world's population that lives in less developed countries. The most frequent examples of higher male expectation of life at birth are in Asia. ${ }^{201}$ An analysis of 78 Asian life tables, mostly from the period 1950-1970, showed higher male expectation of life at birth in $28 \%$ of them. ${ }^{202}$ The countries included India, Pakistan, Sri Lanka, the Khmer Republic, and the Indian populations of Fiji, Malyasia, and Singapore. More recent life tables for Nepal, India, and Pakistan, and recent life tables for Papua New Guinea, also show higher male longevity. ${ }^{203}$ Recent life tables for Indonesia ${ }^{204}$ and Bangladesh ${ }^{205}$ show no difference be-

ages 1-4, Yugoslavia, 1961, 1964. S. Preston, N. Keyritz \& R. Schoen, supra note 192, at 780-87.

${ }^{199}$ Stolnitz, supra note 192, at 25. See text and notes at notes 201-207 infra.

${ }^{200}$ See notes 219, 240 infra. Legal commentators have overlooked this fact. See Key, supra note 5 , at 4.

201 El-Badry, Higher Female than Male Mortality in Some Countries of South Asia: A Digest, 64 J. Am. STATistical A. 1234 (1969). A measurement problem remains in such studies in determining the accuracy and completeness of the data. Recent advances in demographic technique emphasize adjustments of, and inferences from, incomplete data. Some of these techniques were applied to data for India, Pakistan, and Nepal by the International Data Evaluation Branch of the U.S. Bureau of the Census. The results of different techniques agreed, and the male advantage in expectation of life at birth remained. INDIA PRoFile, supra note 189, at 1-2, 24; U.S. Bureau of the Census, Country Demographic Profiles: Nepal, ISP-DP-21, at 1-2, 22-23, 29 (1979) [hereinafter cited as Nepal Profile]; U.S. Bureau of the Census, Country Demographic Profiles: Pakistan, ISP-DP-24, at 2-3, 23-80 (1980) [hereinafter cited as Pakistan Propile].

${ }^{202}$ Economic Comm'n for Asia and the Far East, United Nations, Comparative Study of Mortality Trends in ECAFe Countries, Asia Population Studies Series No. 14 , at $24,41-42,82-86$ (1973) [hereinafter cited as ECAFE].

${ }^{203}$ Dep't of International Economic and Social Affairs, United Nations, DemoGRAPHIC YeARBOoK 1977 Table 22, at 442-63, U.N. Doc. ST/ESA/STAT/SER. R/6 (1978) (Papua New Guinea, 1970-1975) [hereinafter cited as Demographic Yearbook 1977]; Nepal Central Bureau of Statistics, Nepal in Figures (1979); India Profile, supra note 189, at Table 5; Nepal Profile, supra note 201, at Table 5; Pakistan Profile, supra note 201, at Table A-4; Van de Kaa, Estimates of Vital Rates and Future Growth, New GuineA RESEARCH Bulr. No. 34, Apr. 1970, Table 7, at 1-16.

204 Dep't of Economic and Social Affairs, United Nations, Demographic Yearbook 1970, Table 20, at 710-29 (1971) [hereinafter cited as Demographic YEARBooK 1970]. This is the table cited by Chief Justice Burger to support the comment that "[g]ender-based actua- 
tween the sexes in life expectation. In the Middle East, the most recent tables for Jordan and Iran show higher male longevity. ${ }^{206}$ Even in Third World countries with higher average female longevity, the SMD tends to be smaller than in the United States. ${ }^{207}$

4. Variations in Developed Countries. Professor Kimball's statement would be more accurate if it suggested that lower female mortality is almost universal at older ages, during the past few decades, in the most developed countries. This is a significantly shrunken universe; at most it suggests that some kind of biological difference becomes a significant advantage for older women under the environmental conditions prevailing in developed countries. But variations among and within the most developed countries during the past six decades tend to refute even this modified version of the genetic-difference argument. Such variations are substantial, and they are not correlated with level of development.

With greater economic development, two things tend to happen: overall mortality declines, and SMDs increase. ${ }^{208}$ At the very highest levels of development, however, this relationship breaks down. First, the association between development and mortality weakens; for example, the United States ranks only eighth in the world in female expectation of life at birth and fifteenth in male

rial tables have been in use since at least 1843 and their statistical validity has been repeatedly verified." City of Los Angeles v. Manhart, 435 U.S. 702, 725-26 \& n.2 (1978) (Burger, C.J., concurring in part and dissenting in part). This is an astonishing table to cite for that claim, because, for sixty countries, it reports unisex data only. Furthermore, this table shows higher male expectation of life at birth in six countries.

${ }^{203}$ Demographic Yearbook 1977, supra note 203, Table 22, at 442-63. The countries mentioned in text and notes at notes 203-205 accounted for $22.5 \%$ of the world's population in 1977. U.S. Bureau of the Census, World Population 1977 ISP-WP-77 (1978).

${ }^{206}$ Demographic Yearbook 1977, supra note 203, Table 22, at 442-63. Other examples of higher male expectation of life at birth include El Salvador (1930), Guatemala (1930, 1949-1951), Nigeria (1965-1966), Upper Volta (1960-1961), Liberia (1971), and Asians in South Africa (1950-1952). E. Arriaga, Mortality Deculne and Its Demographic Erfects in Latin America 46 (1970); Demographic Yearbook 1977, supra note 203, Table 22, at 44263; Dep't of Economic \& Social Affairs, United Nations, Demographic Yearbook 1974 Table 33, at 1004-34, U.N. Doc. ST/ESA/STAT/SER. R/3 (1975) [hereinafter cited as DEMographic Yearbook 1974]. See also Demographic Yearbook 1970, supra note 204, Table 20, at 710-29 (equal life expectancy in Bolivia) (1950).

${ }^{207}$ Demographic Yearbook 1977, supra note 203, Table 22, at 442-63. Dr. Pressat, who studied pre-industrial European and contemporary developing countries on the theory that they most closely approximated the state of nature, concluded that any female biological advantage is less than two years. Pressat, supra note 130 , at 105 . If one accepts his assumption that biological advantage is best measured in the state of nature, the advantage disappears entirely in light of the prehistoric data. See text at note 196 supra.

${ }^{208}$ See ECAFE, supra note 202, at 16-19, 41. 
expectation of life at birth, ${ }^{208}$ although it is approximately fourth in gross national product per capita. ${ }^{210}$ The association between greater economic development and greater SMDs also breaks down. European nations or political subdivisions with lower levels of economic development (Northern Ireland, Denmark) and also places with higher levels of development (Switzerland, Norway) have smaller SMDs than the United States. Another group of countries, with no clear developmental pattern, has larger SMDs: the Soviet Union, Finland, and France. ${ }^{211}$ The absence of any pattern contradicts the simple hypothesis that advanced economic development is a sufficient condition for female biological superiority to manifest itself.

The range of SMDs in Europe varies from 5.34 years for 1969. 1971 in the German Democratic Republic to 10 years in the U.S.S.R. in 1971-1972. ${ }^{212}$ There is no technique for defining which of these SMDs might represent the "normal" excess of male mortality over female mortality. In lieu of such a technique, Professor Preston used an orthogonal regression to predict "expected" male mortality from female mortality. In studying deviations from the predicted figures, he noted geographic and cultural clustering. One such pattern appears in Europe, where a central band of countries exhibiting relatively high male mortality separates two areas of relatively high female mortality. ${ }^{213}$ This pattern suggests a nonbiological explanation, as does the fact that mortality patterns of European countries do not persist among their emigrant populations. ${ }^{214}$

There are also puzzling variations within individual developed countries. In the United States in 1969-1971, the male expectation of life at birth ranged from 60.92 years in the District of Columbia to 71.02 years in Hawaii. ${ }^{216}$ The female range extended from 70.5

209 Demographic Yearbook 1977, supra note 203, Table 22, at 442-63.

210 Statistical ABSTract, supra note 6, at 910. OPEC countries were excluded from this comparison.

211 United Nations, Statistical Yearbook 1977, Table 19, at 80-85, U.N. Doc. ST/ ESA/STAT/SER. S/5 (1978); StatisTicaL ABSTRact, supra note 6, at 904, 910.

${ }^{212}$ Demographic Yearbook 1977, supra note 203, Table 22, at 442-63.

${ }_{213}$ S. PRESTON, supra note 126, at 138. Preston speculates that regional variations in blood group and somatotype might play a role. Id. at 141 . But see text and note at note 214 infra.

214 See S. Preston, supra note 126, at 139; Krueger \& Moriyama, Mortality of the Foreign Born, 57 Am. J. Pud. Health 496 (1967). See also S. Ledermann, Alcool, AlcoolISME, ALCOOLISATION 77-89 (1964) (another regional analysis).

${ }^{215}$ Greville, supra note 32, at 4-14. Greville discounts racial composition as a factor in 
years in the District of Columbia to. 77.01 years in North Dakota. ${ }^{216}$ Thus the range among males by geographic areas was 10.1 years, larger than the national difference between the sexes, and the average for men in Hawaii was higher than the average for women in the District of Columbia. The SMD by state ranged from 5.77 years in Hawaii to 9.0 years in Wyoming. ${ }^{217}$ The former Confederate states all have SMDs larger than the national figure, and the industrialized Northern states all have SMDs below the national figure, ${ }^{218}$ further confounding the notion that SMDs uniformly increase with development. 218

Another geographic variation in SMD is that between urban and rural residents. A number of studies have documented male mortality advantages in rural areas, ${ }^{220}$ a result some scholars attribute to greater discrimination against women in rural households. ${ }^{221}$ This, again, suggests the importance of behavioral and environmental factors in explaining the SMD.

5. Animal Studies. Proponents of the genetic argument have claimed that greater female longevity is almost universal in the animal kingdom. ${ }^{222}$ This claim is derived from a 1948 summary of

Hawaii's superior male longevity. Id. at 4-15.

218 Id. at 4-14.

217 Id.

218 Id.

210 Some subpopulations in both the United States and other countries have recorded a male expectation of life at birth that exceeded the female. These include Negroes in 19191921, id., all of Hawaii in 1910 and 1919-1920, Gardner \& Schmitt, Ninety-Seven Years of Mortality in Hawaii, 32 HawaII MEd. J. 297, 299 (1978), ethnic Hawaiians in 1910 and 1920, C. Park, R. Gardner \& E. Nordyke, Life Tables by Ethnic Group for HawaII, 1920-1970, at 12-14 (Hawaii State Dep't of Health R \& S Report No. 26, June 1979), Japanese in Hawaii in 1910, id. at 12, and Filipinos in Hawaii in 1920 and 1950, id. at 13, 20. Other examples of provincial SMDs that were negative despite a positive national SMD include five Japanese prefectures in various years between 1920 and 1935, I. TAEUBER, The Population OF JAPAN 294 (1958). See also Hanley, Fertility, Mortality, and Life Expectancy in PreModern Japan, 28 Population Stud. 127, 139-40 (1974). A more recent example in a less developed country is Sabah in Malaysia, Demographic Yearbook 1977, supra note 203, at 456.

${ }^{220}$ L. Dublin, A. LotKa \& M. Spiegelman, supra note 191, at 129; Martin, supra note 130, at 289; World Health Organization, Health Trends and Prospects, 1950-2000, 27 World Health Statistical Rep. 672, 688 (1974). But see E. Kitagawa \& P. Hauser, supra note 130 , at 119 (finding that this difference no longer exists in the United States).

221 R. Kennedy, The Irish: Emigration, Marriage, and Fertility 56-64 (1973); S. Preston, supra note 188, at 149; N. Whliamson, supra note 190, at 100.

${ }^{222}$ Kimball, supra note 4, at $88 \mathrm{n} .9$ (citing R. RETHERFORD, supra note 130, at 101). Retherford, however, explicitly rejects the inference that Kimball draws from him: that genetic differences are the primary cause of SMDs. Id. at 101. 
such studies, ${ }^{223}$ and from four species of laboratory animals: fruit flies, beetles, spiders, and rats. ${ }^{224}$ More recent research indicates that among mammals, higher female mortality is as likely as higher male mortality. ${ }^{225}$

6. Other Evidence. The most superficially convincing argument for a biological basis for SMDs was made by Professor Madigan, who studied both nuns and brothers in Roman Catholic religious teaching orders. ${ }^{226} \mathrm{He}$ eliminated nonwhites, the previously married, and those who entered religious life after the age of 27, assuming that his choice of subjects controlled for life style, occupation, marital status, and general sociocultural stress that might affect mortality. He concluded that biological factors played the chief part in explaining the superior longevity of the sisters. ${ }^{227} \mathrm{But}$ several researchers have been critical of his interpretations. ${ }^{228}$ The most serious problem with his research design is that the brothers were permitted to smoke and drink. ${ }^{229}$ Because differences in smoking behavior account for a large portion of the SMD in the general population, ${ }^{230}$ Professor Madigan's study is of no probative value.

Another argument for a biological basis for SMDs is based on the large number of sex-linked diseases or developmental disorders that usually affect only men. ${ }^{231}$ But the fatalities from such sex-

${ }^{223}$ Retherford cites Hamilton, The Role of Testicular Secretions as Indicated by the Effects of Castration in Man and by Studies of Pathological Conditions and the Short Lifespan Associated with Maleness, in 3 Recent Progress in Hormone Research 257 (1948). R. RETHERFoRD, supra note 130, at 9. But Hamilton notes many exceptions, and many of the studies reflect out-of-date or dubious methodologies, such as observations of sex ratios in herds.

224 Kallman \& Jarvik, Individual Differences in Constitution and Genetic Background, in Handbook of Aging and the Individual: Psychological and Biological Aspects 216, 230-31 (J. Birren ed. 1959); Gerber, supra note 5, at $1220 \mathrm{n} .81$ (citing Moore, Mortality and Morbidity in the Population, in 1 AGING AND Society 195, 201 (M. Riley \& A. Foner eds. 1968)).

${ }^{225}$ Caughley, Mortality Patterns in Mammals, 47 Ecology 906 (1966); Waldron, supra note 177 , at 349 . The only mammals with higher male mortality reported in Hamilton, supra note 223, are rats and humans. Male mice outlived females, and studies of cattle produced inconsistent findings. Id. at 262-63.

${ }^{228}$ Madigan, Are Sex Mortality Differentials Biologically Caused?, 35 Mrlbank MemoRIAL FUND Q. 202 (1957).

227 Id. at 221.

${ }^{228}$ R. RETHERFoRD, supra note 130, at 13; Key, supra note 5, at 6; Waldron, supra note 177 , at 350 .

${ }^{228}$ Madigan, supra note 226, at 204.

${ }^{230}$ See text and notes at notes 248-249 infra.

231 Herden, Causes of Excess Male Mortality In Man, 3 Acta Genetica ex Statistica MEDICA 351 (1952). By "sex-linked disease" is meant one related to defects or traits carried 
linked diseases are too rare to have. any substantial effect on SMDs. ${ }^{232}$

A final argument that there is a biological basis for SMDs relies on the possible protective effects of female hormones. Some studies suggest that estrogen protects against cardiovascular disease in premenopausal women, ${ }^{233}$ perhaps because it inhibits cholesterol-deposit formation. ${ }^{234}$ Other studies, however, suggest that there is no such relationship ${ }^{285}$ or even that the relationship is reversed under some conditions. ${ }^{238}$ Nor do male hormones seem to be the operative influence in heart disease. ${ }^{237}$ Even if estrogen does turn out to provide significant protection against cardiovascular disease, this would not make a case for a universal female advantage strong enough to justify using segregated actuarial tables. Some $32.1 \%$ of the female labor force, ${ }^{288}$ and virtually all women collecting annuities, are beyond the age of menopause. ${ }^{239}$

Investigating the differences caused by hormones may be the most promising avenue for research on biological sources of the SMD. Yet it is doubtful that much of the current differential can be attributed to hormones. For even if some female advantage were biologically based, the sudden widening of the gap in recent years to six, seven or even ten years must be explained by other variables.

\section{The Instability of SMDs}

Perhaps the most difficult datum to reconcile with the biologi-

on the pair of human chromosomes that determine sex.

${ }^{232}$ Waldron, supra note 177 , at 356, calculates that deaths due to sex-linked conditions account for less than $2 \%$ of the excess deaths experienced by males up to the end of the reproductive years.

${ }^{233}$ See Higano, Robinson \& Cohen, Increased Incidence of Cardiovascular Disease in Castrated Women, 268 New England J. MEd. 1123 (1965).

2s4 $R$. RETHERFoRD, supra note 130 , at 15.

2ss Ritterband, Jaffe, Densen, Magagna \& Reed, Gonadal Function and the Development of Coronary Heart Disease, 27 Circulation 237 (1963); Waldron, supra note 177, at 352.

236 See Mann \& Inman, Oral Contraceptives and Death from Myocardial Infarction, Brit. MED. J., May 3, 1975, at 245.

237 Waldron, supra note 177 , at 352 .

238 Estimated from 1977 data for women aged 45 and older in Bureau of Labor Statistics, U.S. Dep'T of Labor, HaNdBook of Labor Statistics 1978, at 29 (1979).

239 Estrogen might protect premenopausal women from heart disease by delaying atherosclerosis. Smoking and cholesterol levels are implicated as causes of atherosclerosis. $R$. RETHERFoRD, supra note 130, at 15 . Thus the possible protective benefits of estrogen might not be needed by women and men who do not smoke or eat high cholestorol diets. 
cal argument is the rapid change in SMDs in recent years. In the United States, within the adult life of a single annuitant, the SMD measured by the expectation of life at birth increased from 1.0 year in 1920 to 7.7 years in $1970,{ }^{240}$ the SMD at age 65 increased proportionately. ${ }^{241}$ The general trend in Europe has also been toward an increasing SMD. ${ }^{242}$ Demographers have approached the problem by asking why men in the developed countries die prematurely. This formulation is suggested by the fact that the male expectation of life in the United States is exceeded at birth in Puerto Rico, ${ }^{243}$ at age 35 in Albania, Portugal, and Costa Rica, ${ }^{244}$ and at age 65 in the Philippines, Panama, El Salvador, Puerto Rico and Mexico. ${ }^{245}$

Recent studies confirm that the widening of SMDs up to 1970 may be traced principally to higher male mortality from arteriosclerotic heart disease, malignant neoplasms of the respiratory system, bronchopulmonic disease, motor vehicle and other accidents, cirrhosis of the liver, and suicide. ${ }^{246}$ These causes of death accounted for three-fourths of the SMD in the United States in 1967. Behavioral factors such as smoking, drinking alcohol, reckless driving, and the "coronary-prone" or "Type A" personality are implicated in the etiology of each. ${ }^{247}$

The effects of changes in these factors are most dramatically

240 Statistical Abstract, supra note 6, at 70. Female mortality rates in 1920 exceeded those of men for ages 20-39. S. Preston, N. Keyfitz \& R. SchoEn, supra note 192, at 73235 .

${ }^{241}$ Compare S. Preston, N. Keyfitz \& R. Schoen, supra note 192, at 732-35 (SMD at age 65 was .528 years in 1920) with U.S. Public Health Service, supra note 183, at 8-11 (SMD at age 65 was 3.84 years in 1969-1971).

${ }^{242}$ Nineteen of twenty-nine European places for which post-1945 life tables were available had steadily increasing SMDs measured by expectation of life at birth. DEP'T of EcoNomic \& Social Affairs, United Nations, Demographic Yearbook 1960, at 606-08 (1961); Dep't of Economic \& Social Affairs, United Nations, Demographic Yearbook 1964, at 620-22 (1965); Demographic Yearbook 1970, supra note 204, at 724-26; Demographic YearBooK 1974, supra note 206, at 1026-32; Dep'T of Economic \& Social AfFaIRs, United NATIONS, DEMOGRAPHIC YEARBOOK 1976, at 428-32, U.N. Doc. ST/ESA/STAT/SER. R/5 (1977); Demographic Yearbook 1977, supra note 203, at 456-60.

${ }^{243}$ United Nations, supra note 211 , Table 19, at 80-85.

244 Data for about 1960, cited in S. Preston, supra note 126, at 1.

${ }^{245}$ S. Preston, N. Keyritz \& R. Schoen, supra note 192, at 220, 456, 560, 564, 600, 768.

${ }^{248}$ E.g., Waldron, supra note 177 , at 350.

${ }^{247}$ Id. For a similar analysis of data from the Soviet Union, which has the largest national SMD in the world, see Dutton, Changes in Soviet Mortality Patterns, 1959-77, 5 Population \& Dev. REv. 267 (1979). Dutton tentatively but persuasively attributes much of the increased mortality among Soviet males to increased consumption of alcohol; he also notes, $i d$. at 289 n.2, that increased consumption of tobacco may have played a role. 
illustrated by smoking. Increased male smoking appears to have accounted for $75 \%$ or more ${ }^{249}$ of the enormous $1910-1962$ increase in SMD in the United States. But recently millions of men have quit smoking, ${ }^{250}$ and women represent the fastest-growing group of new smokers. ${ }^{251}$

Other contributors to SMD are also changeable, and some appear to be changing. The physical activity required by the typical job has declined, and this is associated with higher mortality from heart disease. ${ }^{252}$ The historic predominance of males in the labor force implies that they might have been affected disproportionately. But now, nearly half the adult population of both sexes is exercising at least once a week, and men exercise more strenuously than women. ${ }^{25 s}$ Occupational hazard was once an important contributor to SMDs, but jobs have become less hazardous, ${ }^{254}$ and women are entering jobs in which they were previously not found, including hazardous ones. ${ }^{285}$ There are many hints in the literature that job-related stress contributes to the higher mortality of males, and declining occupational segregation might equalize this fac-

248 R. Retherford, supra note 130 , at 76-79. See S. Preston, supra note 126 , at 86-97 (smoking is the "major cause" of mortality changes). Kimball, supra note 4, at 107 n.58, assumes that genetic differences explain the residual-the part of the SMD not otherwise accounted for by Retherford's data. But Retherford clearly indicates, R. RETHERFORD, supra note 130 , at 12,101, that genetic differences could not account for so rapid an increase, and he explicitly warns against attempting to interpret the residual, id. at 122.

${ }^{219} \mathrm{~S}$. Preston, Analysis of a Change in Western Mortality Patterns 64, 137 (Ph.D. dissertation, Economics, Princeton University, 1968).

${ }^{280}$ Statistical ABSTract, supra note 6, at 126.

${ }^{251}$ See Lewis \& Lewis, The Potential Impact of Sexual Equality on Health, $297 \mathrm{NEw}$ England J. Med. 863, 865 (1977). Compare U.S. Bureau of the Census, Statistical ABStract of the United States, 1969, at 80 (90th ed. 1969) with Statistical Abstract, supra note 6 , at 126.

${ }^{232}$ Menotti \& Puddu, Death Rates Among the Italian Railroad Employees, with Special Reference to Coronary Heart Diseases and Physical Activity at Work, 11 ENvironmental Research 331 (1976); Paffenbarger \& Hale, Work Activity and Coronary Heart Mortality, 292 New England J. MEd. 545 (1975). Earlier studies are reviewed in S. Preston, supra note 126 , at $41-42$.

${ }^{253}$ Statistical AbStracr, supra note 6, at 121.

234 See R. RETHERFORD, supra note 130 , at $6,29$.

2ss The "index of dissimilarity," which indicates the percentage of women that would have to change occupations in order for the sexes to have identical occupational distributions, has slowly but steadily declined from 44.9 in 1965 to 42.3 in 1978. The data upon which these calculations are based come from Statistical ABstract, supra note 6, at 415. In manufacturing and construction, the percentage of workers who are women rose by one point between 1977 and 1979. The percentage of all women workers who are in these industries increased from $17.7 \%$ to $18.2 \%$. 25 Bureau of Labor Statistics, U.S. Dep'r of Labor, Employment and Earnings 160 (1978); 27 id. at 181 (1980); Bureau of Labor Statistics, supra note 238 , at 564-75. 
tor. ${ }^{258}$ Women benefited during this century from the decline in maternal mortality and from techniques for detecting cancers of the breast and female reproductive organs. ${ }^{257}$ But a new blood test for detecting prostate cancer may become as beneficial to men as the Pap smear has been to women, ${ }^{258}$ and new techniques of treating cardiovascular disease may disproportionately benefit men. ${ }^{259}$

Effects of such changes are beginning to appear in mortality data, and may indicate that a decline in the SMD is also beginning. Between 1971 and 1977, the male crude death rate dropped 0.9 per thousand, while the female rate dropped 0.4 per thousand. ${ }^{260}$ The age-specific death rates for both males and females between ages 45 and 75 declined during these years, but the rate of male decline was faster-three times faster for males aged 55-64,

${ }^{258}$ The evidence on job-related stress at this writing does not suggest any clear pattern. See S. Preston, supra note 126, at 66-68; Johnson, Recent Trends in Sex Mortality Differentials in the United States, J. Human STREss, Mar. 1977, at 22-23; Waldron, supra note 177, at 355, 358; Waldron, Zyzanski, Shekelle, Jenkins \& Tannebaum, The Coronary-Prone Behavior Pattern in Employed Men and Women, J. Human Stress, Dec. 1977, at 2. But see Gerber, supra note 9, at 1218-19 (SMDs not affected by females entering labor force).

237 Enterline, supra note 177, at 324.

${ }^{258}$ See Foti, Cooper, Herschman \& Malvaez, Detection of Prostatic Cancer by SolidPhase Radioimmunoassay of Serum Prostatic Acid Phosphatase, 297 NEw England J. MED. 1357 (1977).

259 There is conflicting evidence on whether differential susceptibility to infectious disease contributed to the SMD. Compare 2 A. Mrtra, India's Population: Aspects of QualiTY AND Control 806 (1978), S. Preston, supra note 188, at 121-23, and Gove \& Hughes, Possible Causes of the Apparent Sex Differences in Physical Health: An Empirical Investigation, 44 AM. Soc. REv. 126, 130-31 (1979), with R. RETHERPORD, supra note 130, at 26-29, and Waldron, supra note 177 , at 355-56. Infectious disease is not likely, however, to be an important factor in the future in the developed countries. There is some evidence that women are more willing to seek medical attention. Lewis \& Lewis, supra note 251, at 866-67; Verbrugge, Sex Differentials in Morbidity and Mortality in the United States, 23 Soc. BIOLOGY 275 (1976); Waldron, supra note 177, at 356-57. This could change, but there is no present evidence that it is changing. There is no conclusive evidence that dietary differences have contributed to SMDs in the United States, see S. Preston, supra note 126, at 40-41, 46-50, 64-65, 68-69; Friedmann \& Rosenmann, Comparison of Fat Intake of American Men and Women, 16 Crrculation 339 (1957), but a general reduction in cholesterol intake might disproportionately benefit men because of their higher current death rates from heart disease.

${ }^{260}$ Statistical Abstract, supra note 6, at 72. A decomposition of the difference between the crude rates yielded the components shown in the table below. 
for example. ${ }^{261}$ Effects are beginning to appear in life tables. In Hawaii, the state with the lowest SMD, the SMD at birth dropped almost two full years to 3.93 years in 1975, from 5.77 years in 19691971. ${ }^{262}$ Recent European life tables have shown decreases or fluctuations for the SMD in Albania, Austria, Czechoslovakia, England and Wales, Greece, Hungary, Malta, and Norway. ${ }^{283}$

These data are important because the improvement in male mortality has taken place at exactly those ages that contribute the most to the SMD-those over 50. Moreover, the decline is coming largely from reduced cardiovascular deaths, the cause of death most prominently associated with the SMD. Death rates from heart disease declined by 14.3 per 100,000 women between 1970 and 1977 , but for males the decline was 45.8 per 100,000 . The most dramatic "saving" was among men aged 65 or over, for whom the decline amounted to 418.2 per $100,000 .{ }^{264}$ These data offer the pos-

\begin{tabular}{lcc}
\hline \hline & MALES & FEMALES \\
\hline Total change, 1971-1977 & -0.9 & -0.4 \\
1. Component due to decline in & -1.4 & -1.3 \\
$\quad$ death rates & 0.5 & 0.8 \\
2. Component due to age & 0.0 & 0.1 \\
$\quad$ structure & Interactions of age and rates & \\
\hline
\end{tabular}

The decomposition formula appears in Kitagawa, Components of a Difference between Two Rates, 50 J. AM. Statistical A. 1168 (1955). The decomposition indicates that the decline in death rates is larger for men than women even after taking account of the fact that there are more females in the older ages subject to higher death rates. This casts doubt on the conclusions of one researcher skeptical about a possible decline in SMD, Johnson, supra note 256, at 22. Although he recognizes the contribution played by both rates and changes in the population's age composition, $i d$. at 23 , his use of age-adjusted mortality rates controls composition but fails to identify changes in rates and in the interactions of rates and age composition. A decomposition technique is more convincing. Our use of more recent data also contributes to some of the disparity in conclusions, as does his use of ratios instead of differences. His data, id. at 26-27, show that since 1968 the male-female difference for age-adjusted rates of death from all causes and from major cardiovascular disease has declined. Only the ratio between the male and female rates has increased; this results from a small denominator (the female death rate) getting even smaller.

${ }^{261}$ Statistical ABSTract, supra note 6, at 72.

262 Gardner \& Schmitt, supra note 219, at 298-300; Greville, supra note 32, at 4-14. The national SMD at birth has fluctuated between 7.6 and 7.8 years since 1970. Statistical ABSTRACT, supra note 6, at 70 .

28s Authorities cited note 242 supra. Smaller fluctuations were also recorded in Romania and Yugoslavia.

284 Statistical ABSTract, supra note 6, at 78. There are also limited data that suggest increased female mortality from lung cancer, and from some minor causes of death. Lewis \& Lewis, supra note 251, at 867; Verbrugge, supra note 259, at 279; Waldron, Sex Mortality 
sibility that the SMD might be reduced through improvements in male mortality, and that the improvement will most benefit those males of an age to receive pensions.

The variations in SMD over time and space, and the role of environmental and behavioral factors in explaining the variations, suggest that a biological or genetic explanation is seriously deficient. It might be argued that some of the behavior patterns are biologically caused, but the evidence for this is weak and unpersuasive. The coronary-prone or Type A personality, reckless driving, and suicides, behavioral patterns that disproportionately characterize males, may reflect the generally higher aggressive tendencies of men in industrial societies, and there is in fact some evidence that aggressiveness is related to male sex hormones. ${ }^{265}$ But there are wide individual and cultural variations in the degree of aggressiveness displayed by males. ${ }^{268}$ And neither these traits nor their consequences are limited to men. The Type A personality, for example, substantially increases the risk of coronary heart disease at all ages in both sexes. Post-menopausal Type A women have the same high rates of coronary heart disease as Type A men over 50, and at all ages, Type $B$ men-those without the coronary-prone personality-have the same low rates as Type B women. ${ }^{267}$

\section{The Changing Composition of the Insured Population}

Insurance industry mortality tables are based on the actual experience of annuitants, not on census data or vital statistics for entire populations. ${ }^{288}$ This means that another changing factor is the composition of the insured population. In the cohorts that have recently entered the labor force, pension coverage is much more widespread $^{269}$ and female labor force participation rates are much

Differentials, J. Human Stress, June 1977, at 46; Waldron \& Johnston, Why Do Women Live Longer Than Men?, J. Human Stress, June 1976, at 19, 23-24.

${ }^{285}$ E. MACCOBY \& C. JACKLIN, supra note 133, at 242-47, 274.

${ }^{268}$ See, e.g., R. Dentan, The Semai-A Nonviolent People or Malaya (1968); E. Maccoby \& C. Jackin, supra note 133, at 247,372; M. Mead, SeX and Temperament in Three Primitive Societies (1935).

${ }^{287}$ Waldron, supra note 177 , at 351 . These findings should be considered preliminary, because they are based on small-scale retrospective studies. Large-scale prospective studies show that Type A men are twice as likely as other men to develop coronary heart disease. Id. See also Waldron, Zyzanski, Shekelle, Jenkins \& Tannebaum, supra note 256.

${ }^{268}$ Kimball, supra note 4, at 108.

280 Davis \& Strassen, Private Pension Plans 1960 to 1969: An Overview, Monthly Lab. REv., July 1970, at 45; Skolnick, Private Pension Plans 1950-74, Soc. SecurITY Buld., July 1976, at 3; Yohalem, Employee-Benefit Plans, 1975, Soc. Security BuLL., Nov. 1977, at 19. 
higher ${ }^{270}$ than in the older cohorts whose deaths are the basis of industry tables. For example, data from the birth cohort of 19051911 indicate that only $21 \%$ of privately employed women were covered by pension plans on their longest job, and of those only $55 \%$ are actually receiving benefits. ${ }^{271}$

The most likely women to be covered by a pension were those who had worked continuously, ${ }^{272}$ who had earned a high salary, ${ }^{273}$ and whose longest jobs had been professional and technical, or clerical, ${ }^{274}$ and in the transportation, communication, utilities, finance, insurance, and real estate industries. ${ }^{275}$ Thus, it is possible that the women on whom the annuity tables are based were an elite group whose greater longevity has temporarily exaggerated the SMD in industry tables. ${ }^{276}$ If further research confirms that insurance industry tables do exaggerate the SMD in this way, then changes in the size and characteristics of the insured female population-in addition to all of the other variables that affect the

270 Bureau of LABor Statistics, supra note 238, at 26-27.

271 Thompson, supra note 113 , at 5, 8. This study, although rich in data, is hampered by a flaw in design. Women were included only if they had no husband present in the household. To test whether our findings may be generalized, we turned to data on the total money income of women aged 65 and over in 1975, U.S. Bureau of the Census, Current Population Report, Series P-23, No. 85, Social and Economic Characteristics of the Older Population 23, 27 (1979). These data strongly suggest that the pension benefits of women reported by Thompson probably overstate the work-related income of older married women.

272 Thompson, supra note 113, at 5.

273 Id.

274 Id.

275 Id.

${ }^{276}$ On the association between mortality and socioeconomic status, see note 130 supra. The insurance industry has not published the data necessary to test the hypothesis that their tables are based on an elite group of long-lived females, and the sketchy data that are available conflict. One study by TIAA-CREF reports that there is no difference in the mortality experience of its primary female annuitants (covered working women) and its secondary female annuitants (the wives of covered working men). R. DuNCAN, supra note 117. But this insurance pool consists of upper-level white-collar workers whose overall mortality is likely to be low because of their socioeconomic status, which is shared by their immediate families. A study of Railroad Retirement Board beneficiaries shows "slightly longer life expectancies at all ages 60 and over for female retired employees than for wives and widows of male retired employees." Id. at 1 . In this pool, women workers may have been disproportionately white collar, so that they did not necessarily share the socioeconomic status of male coworkers and their wives. Data on individual annuitants indicate some self-selection by healthy women. Metropolitan Life, supra note 117, at 5 . But this kind of self-selection is less likely to operate in employer-sponsored pension plans, because participation is often mandatory. Data on individual life insurance holders show little difference in the SMD between policy holders and the general population. Id. at 4; SocIETY OF ACTUARIEs, supra note 117, reprinted in U.S. Comm'N oN CrviL RighTs, supra note 115, at 547. Data on employersponsored pension plans are not readily available. 
SMD-may affect the industry's future experience.

\section{E. Implications of the Demographic Evidence}

It is convenient to "explain" sex-based differences as biological in origin, just as it was once fashionable to "explain" racial differences in similar terms. But these "explanations" fail because they are post hoc theorizing with no power to predict changes in SMD. ${ }^{277}$ Characterization is not analysis.

This is not to say that there are no genetic or biological differences that may affect SMDs. But any that may exist are of no help in making predictions because they are overwhelmed by other factors. It would be no help to insurers to identify a biological tendency to a one-year female advantage if environmental and behavioral factors can cause much larger variations in either direction. It seems unlikely that any separable increment of biological advantage will be identified. Further research is likely to reveal increasingly complex interactions of biological, environmental, and behavioral factors, rather than separately measurable years of SMD attributable to separate factors..$^{278}$

Whatever the causes of differential male and female life expectancy, the fact that is most damaging to proponents of segregated tables is that SMDs change rapidly. The most that an insurer can do to reflect these changes is to calculate a new period life table. But that table is constrained by the same assumption as the old one: that the experience of workers who have already died is the best guide to predicting the mortality of young workers who are living. The life table applied to a 20 -year-old in 1980 who will retire in 2030 is based on men who were 20 years old in 1920, 1930, or 1940, and who have already died. But in that century between 1930 and 2030 many unpredictable changes can occur.

The problem is tolerable in predicting overall mortality. Rates can be set conservatively to assure sufficient funds to pay claims arising under any likely set of future conditions. But prediction of SMDs is much more difficult, and an error in either direction is equally serious. Insurers make their predictions without a theoretical basis in biology or sociology, on the basis of recent life tables that might reflect mere historic anomalies in the SMD. There is no future.

${ }^{277}$ The test of a scientific theory is its ability to predict, within specified conditions, the

${ }^{278}$ See R. Retherford, supra note 130, at 12; Kitagawa, supra note 182, at 385. 
reason to believe that the long-term trend reliably predicts even the direction of future changes. Moreover, the magnitude of potential errors is enormous in proportion to the difference being predicted. ${ }^{279}$ Thus an employer who classifies his employees by sex and then attempts to distribute total annuity benefits proportionately between the two groups-the goal of segregated tables-must be very lucky indeed to avoid giving one group significantly more than its "share."

\section{ConClusion}

Equal treatment of individuals and equal outcomes for groups are powerful competing themes in civil rights law, and the tension between the two increases as the conviction spreads that equal treatment will not soon bring group equality for minorities. The result is that we are now in the midst of a profound national debate over affirmative action, and an old-fashioned argument for equal treatment of individuals must distinguish or repudiate each new group-based approach. These developments should not be allowed to obscure the central point. The primary commitment of the statute, and of the American civil rights tradition, is to equal treatment of individuals. The rationales that are offered for attention to groups in the affirmative action context do not apply to actuarial tables, and the debate over such tables should not be caught up in the debate over affirmative action.

Curiously, however, the proponents of segregated tables do not rely on the affirmative action analogy, and generally think racial preferences undesirable. Their insistence on group equality in the actuarial context is inconsistent with their insistence on individual equality in the affirmative action context. The rationales that might be proposed to reconcile these inconsistent views-that Congress surely did not mean to change established practices, or that only inefficient discrimination is prohibited-are essentially hostile to the statute. All of these arguments collapse once it is established that the statute requires equal treatment of individuals. Most of them also fall on their own terms, for sex turns out to be a spurious, weak, and unstable predictor of mortality. Manhart is rightly

279 The 6.7-year change in the SMD at birth in the United States from 1920 to 1970 is $670 \%$ of the $1920 \mathrm{SMD}$, and $88 \%$ of the $1970 \mathrm{SMD}$. An $88 \%$ increase in current human longevity would create a life expectancy of over 130 years. 
decided, and the Court should not hesitate to apply its logic to all other forms of employer-sponsored insurance plans. 